\title{
ע Suomea toisena kielenä puhuvan työntekijän erilinjaiset vuorot kokousvuorovaikutuksessa
}

\author{
InKeri Lehtimaja Ja LARi Kotilainen
}

\section{Johdanto}

Globalisoituvassa työelämässä yhä useampi työntekijä käyttää työpaikallaan kieltä, joka ei ole hänen ensimmäinen tai vahvin kielensä. Toisella kielellä toimimisen on osoitettu asettavan työntekijöille monenlaisia haasteita. Jäppisen $(2010,2011)$ mukaan kakkoskieliset puhujat saattavat kokea jotkin suomenkieliset vuorovaikutustilanteet vaikeiksi, väsyttäviksi ja jopa pelottaviksi, vaikka työelämän rutiinitoimenpiteet sujuisivatkin. Tällöin he saattavat jättäytyä kuulijan rooliin, vaihtaa kieltä siksi, etteivät halua kuluttaa toisten aikaa, tai esimerkiksi kokousten pitkittyessä väsyä niin, että työtehtävien suorittaminen hankaloituu. Tällaisia tuloksia on saatu paitsi Suomesta myös monista muualla Euroopassa tehdyistä tutkimuksista, jotka ovat pohjautuneet pääosin haastatteluihin: työntekijöiden rajalliset taidot työpaikalla käytettävissä kielissä voivat hidastaa työtehtävien hoitamista, heikentää vuorovaikutuksen tehokkuutta sekä vaikeuttaa tilanteisiin osallistumista ja sitä kautta vaikkapa tiedon jakamista (esim. Lüdi, Höchle \& Yanaprasart 2010; Lønsmann 2014; Negretti \& Garcia-Yeste 2015).

Tämän artikkelin tavoitteena on kuvata, miten kakkoskielisyys ilmenee työkokousten vuorovaikutuksessa ja minkälaisia erityisiä ongelmia kielitaidon rajallisuudesta kokouksissa seuraa. ${ }^{1}$ Käytämme tutkimuksessa videoaineistoa, jota analysoimme keskustelunanalyysin keinoin (esim. Stevanovic \& Lindholm toim. 2016). Olemme valinneet metodin nimenomaan sitä silmällä pitäen, että keskustelunanalyysin avulla on mahdollista havainnoida autenttisia tilanteita ja kuvata mikrotason ilmiöiden kautta, miten vuorovaikutuksen haasteet ilmenevät. Aineistonamme on työkokouksia, jotka on videoitu suomalaisen kulttuurialan säätiön ja sen yhteistyökumppanien tiloissa. Kokouksissa käytetään suomea, venäjää ja jossain määrin englantia, ja osallistujina on kaikkien kolmen kielen kakkoskielisiä puhujia. Tässä artikkelissa keskitymme kuiten-

1. Artikkeli on toteutettu Koneen Säätiön rahoittamassa Suomen kielen tilanteinen oppiminen -hankkeessa kirjoittajien tasavertaisen yhteistyön tuloksena (nimien järjestys on arvottu). Lopputuloksen saavuttamisessa ovat auttaneet suuresti professori Salla Kurhila ja kaksi anonyymia refereetä, joita kaikkia kiitämme lämpimästi. 
kin suomenkieliseen vuorovaikutukseen ja kakkoskielisillä viittaamme analyyseissa suomea toisena kielenä puhuviin työntekijöihin, joiden ensimmäinen kieli on aineistossamme poikkeuksetta venäjä. ${ }^{2}$

Vaikka kakkoskieliset keskustelut ovat jo pitkään olleet keskusteluntutkimuksen kiinnostuksen kohteena, työelämävuorovaikutuksen kontekstista tutkimusta on vähemmän (ks. esim. Hazel \& Svennevig 2018: 3). Kakkoskielisen työelämävuorovaikutuksen ongelmatilanteiden analysoitavuutta keskustelunanalyysin näkökulmasta hankaloittaa se, että tässä kontekstissa kieleen liittyvät ongelmat pyritään usein ohittamaan (esim. Firth 2009) ja ne voivat siksi jäädä piiloon. Näin on myös käyttämässämme aineistossa, jossa kielelliset ongelmat nostetaan eksplisiittisesti puheenaiheeksi melko harvoin. Tästä huolimatta tutkimissamme kokouksissa esiintyy vuorovaikutuksen ongelmakohtia, joista monilla voi myös arvioida olevan yhteys kielitaitoon. Tarkastelumme kohteeksi olemme valinneet sellaiset vuorovaikutuksen etenemisen (progressivity, Stivers \& Robinson 2006) ongelmakohdat, jotka liittyvät kakkoskielisen työntekijän responsiivisiin vuoroihin. Käsittelemämme ongelmavuorot poikkeavat keskustelun normeista siten, että ne ovat erilinjaisia aloittavan toiminnon kanssa ja siksi merkitykseltään tai toiminnalliselta linjaukseltaan epäselviä tai riittämättömiä. Tutkimuksemme tavoitteena on vastata seuraavaan kaksiosaiseen kysymykseen: minkälaisia kakkoskielisten työntekijöiden ongelmallisia erilinjaisia vuoroja aineistossa esiintyy, ja miten niihin reagoidaan? Varsinaisen tutkimuskysymyksemme lisäksi pohdimme, millä perusteilla aineiston vuorovaikutuksen ongelmakohdat voidaan yhdistää nimenomaan osallistujien kakkoskielisyyteen.

Aihe on hyvin ajankohtainen, sillä maahanmuuttajataustaisten työllistyminen on yksi yhteiskuntamme päähaasteista. Vaikka kielitaidon ja työllistymisen suhde on monisyinen, monien tutkimusten mukaan kielitaidon kehittyminen parantaa työmahdollisuuksia (esim. Larja \& Sutela 2015: 75, 82; Nieminen 2015: 130-131; Budría, Colino \& Martínez de Ibarreta 2018; Aldashev, Gernandt \& Thomsen 2009; Dustmann \& Fabbri 2003). Tämä on erityisen selvää korkeakoulutettujen maahanmuuttajien kohdalla: korkeakoulutusta vaativat tehtävät ovat usein käsitteellistä, kielellistynyttä työtä, ja siksi niissä tarvitaan käytännössä yleensä vähintään B2-tasoista kielitaitoa (esim. Komppa, Jäppinen, Herva \& Hämäläinen 2014: 14; Larja \& Sutela 2015: 75). Kielitaidon taso on erityisen merkityksellinen juuri Suomen venäjänkielisille maahanmuuttajille, sillä heidän joukossaan korkeakoulutettujen määrä on monia muita maahanmuuttajaryhmiä suurempi ja lisäksi monet ovat ylikoulutettuja nykyisiin työtehtäviinsä (Varjonen, Zamiatin \& Rinas 2017: 34-36). Uskomme, että artikkelin tuloksia on mahdollista soveltaa ensinnäkin sen ideoimiseen, miten monikielisten työyhteisöjen kokousvuorovaikutusta voisi sujuvoittaa - erityisesti molemminpuolisen ymmärrettävyyden kannalta. Toiseksi tulokset auttavat pohtimaan, miten edistyneiden kielenoppijoiden työkielitaitoa ja tätä kautta mahdollisuuksia toimia työelämässä voisi kehittää.

2. Puhujien jakaminen ensikielisiin - tai äidinkielisiin - ja kakkoskielisiin ei ole missään nimessä ongelmatonta (ks. esim. Lehtonen 2015: 308-311). Tämän aineiston osalta käsittelemme kysymystä tarkemmin luvussa 2. 
Esittelemme artikkelimme aluksi, luvussa 2, työelämän ja kakkoskielisyyden yhdistävää tutkimusta ja kerromme tarkemmin aineistostamme ja sen erityispiirteistä. Luvussa 3 esittelemme analyyttiset pääkäsitteemme ja erityisesti sitä keskustelua, jota keskustelunanalyytikot ovat käyneet saman- ja erilinjaisuudesta. Luvuissa 4-6 analysoimme eri tavoin ongelmallisia kakkoskielisten työntekijöiden vuoroja. Artikkelimme loppuluvussa 7 pohdimme analyysin implikaatioita ja erityisesti sitä, mitä havaintomme kertovat sellaisesta työelämän vuorovaikutuksesta, johon osallistuu myös kakkoskielisiä suomen puhujia.

\section{Aineisto, työelämän kieli ja monikieliset kokoukset}

Asiantuntijaorganisaatioiden kielenkäyttöä on tutkittu monista näkökulmista. Autenttisiin aineistoihin perustuvissa suomen kielen tutkimuksissa on viime vuosina käsitelty niin kirjoitettuja tekstejä (esim. Tiililä \& Karvinen toim. 2017; Honkanen 2012) ja puhuttua vuorovaikutusta (esim. Kurhila \& Lehtimaja 2018; Pälli \& Lehtinen 2015; Stevanovic 2013) kuin näiden yhdistelmiä (esim. Mikkola 2014a; Nissi \& Lehtinen 2016). Monissa tutkimuksissa on keskitytty myös työelämäkielen ja kakkoskielisyyden suhteeseen (esim. Jäppinen 2010, 2011; Kalliokoski 2017; Komppa 2015; Puhe ja kieli -lehden erikoisnumero 4/2011; Strömmer 2017; Virtanen 2017), mutta tutkimukset on toteutettu pääosin haastattelumetodilla (vrt. kuitenkin terveydenhuollon alalta Paananen 2016, 2019; Lehtimaja tulossa 2019; Kurhila \& Lehtimaja tulossa 2019).

Monet työelämätutkimukset korostavat puhutun vuorovaikutuksen merkitystä organisaatioissa - niiden muodostumisessa, ylläpitämisessä ja uusiutumisessa. Alan klassikon Bodenin (1994: viii) termein organisaatiot puhutaan olemassa oleviksi. Yksi keskeisimmistä ja eniten työntekijöiden aikaa vievistä työelämän puhumisen paikoista ovat erilaiset kokoukset, joita on tutkittu keskustelunanalyysinkin keinoin jo melko paljon (ks. kooste Svennevig 2012). Tämäkin tutkimus perustuu kokousaineistoon: käyttämämme videoaineisto koostuu noin 20 tunnista monikielistä kokousvuorovaikutusta. Aineisto on kuvattu marraskuun 2017 ja kesäkuun 2018 välillä suomalaisen kulttuurialan säätiön työkokouksissa sekä säätiön että sen yhteistyökumppanien tiloissa. Kaksi aineiston yhteensä viidestätoista kokouksesta käydään kokonaan suomeksi, ja yksi on lähes kokonaan venäjänkielinen. Muissa kieltä vaihdellaan suomen, venäjän ja muutamissa kokouksissa myös englannin välillä (ks. kokousten kielistä tarkemmin Kotilainen \& Lehtimaja tulossa 2019).

Vaikka erilaisista kokouksista ja niiden piirteistä ei ole helppo luoda kattavia taksonomioita, kuvaamamme kokoukset eroavat joissakin suhteissa tyypillisistä kokouksista (ks. esim. Menz 2017; Svennevig 2012). Ne ovat luonteeltaan vapaamuotoisia (Boden 1994: 86-87); niissä ei noudateta eksplisiittisesti esiin nostettua esityslistaa, eikä niitä johda puheenvuoroja jakava puheenjohtaja. Silti tilanteet poikkeavat monin tavoin arkivuorovaikutuksesta, eli ne edustavat institutionaalista vuorovaikutusta (esim. Raevaara, Ruusuvuori \& Haakana 2001): Kokouksilla on ensinnäkin jokin säätiön käynnissä oleviin hankkeisiin liittyvä tavoite, johon pyrkiminen jäsentää vuorovaikutusta. Kokouksissa esimerkiksi suunnitellaan tulevia tapahtumia tai apurahahakuja sekä kes- 
kustellaan erilaisista yhteistyökuvioista. Kokousten osallistujat eivät myöskään ole virallisen puheenjohtajan puuttumisesta huolimatta lähtökohtaisesti tasa-arvoisia, vaan he edustavat erilaisia institutionaalisia rooleja. Tämän artikkelin esimerkeissä esiintyy muun muassa säätiön johtaja (Risto), hankkeita vetäviä välitason johtajia (esim. Katja), hanketyöntekijöitä (esim. Jelena ja Olga) ja yhteistyökumppanien edustajia (Ulla ja Sari).

Institutionaalisten roolien lisäksi työntekijöiden asemaan työpaikan vuorovaikutustilanteissa saattaa vaikuttaa myös heidän asemansa tietyn kielen puhujina. Videoilla esiintyvät 19 henkilöä ovat (ainakin suulliselta) kielitaidoltaan sekalainen ryhmä. Noin puolet heistä puhuu ensikielenään suomea ja puolet venäjää. Sekä ensikieleltään venäjänkielisten suomen kielen taito että ensikieleltään suomenkielisten venäjän taito vaihtelee huomattavasti. ${ }^{3}$ Pyrimme kuitenkin välttämään analyysiemme pohjaamista vuorovaikutuksen ulkopuolisiin kategorioihin, eli seuraamme sitä keskustelunanalyysin periaatetta, että analyysin tulisi perustua luokitteluihin, jotka nousevat jollain tavalla esille varsinaisesta vuorovaikutuksesta (ks. kakkoskielisyyteen liittyen esim. Hazel \& Svennevig 2018: 4). Tällainen kokouksiin osallistuvien itsensä relevantiksi merkitsemä kategoria on juuri kakkoskielisyys, johon orientoidutaan aineistossamme esimerkiksi nostamalla kielenvalinta topiikiksi, vaihtamalla kieltä tai varmistamalla ymmärtäminen kysymällä asiaa eksplisiittisesti. Näin käsitettynä kakkoskielisyys ei ole sama asia kuin ei-ensikielisyys; esimerkiksi ensikielenään venäjää puhuvaan Katjaan ei aineistossa orientoiduta suomen kakkoskielisenä puhujana. Kakkoskielisyys on silti nostettu relevantiksi kategoriaksi joissain kohdin aineistoamme kaikkien niiden osallistujien kohdalla, joiden erilinjaisia vuoroja tässä artikkelissa käsitellään. ${ }^{4}$

Se, että aineistossamme on suomea toisena kielenä puhuvia työntekijöitä, näkyy kokouksissa monin tavoin. Vuorovaikutus sisältää esimerkiksi jonkin verran piirteitä, joita tyypillisesti liitetään kakkoskieliseen keskusteluun (esim. sanahakuja ja itsekorjauksia). Näiden käsittely on kuitenkin aineistossamme yleensä hyvin sujuvaa. Silmiinpistävämpiä ovatkin tapaukset, joissa kakkoskielisen vuoro tuntuu sopivan huonosti kontekstiin ja joissa se saattaa tästä syystä johtaa ongelmiin vuorovaikutuksessa. Tarkastelemme näitä tapauksia erilinjaisuus-käsitteen kautta.

\section{Erilinjaisuus vuorovaikutuksen ongelmakohtana}

Etnometodologinen keskustelunanalyysi tarkastelee vuorovaikutusta jäsentyneenä toimintana, jossa jokainen vuoro asettaa tiettyjä odotuksia seuraavalle vuorolle toiminnan näkökulmasta. Tätä vastaanottajan velvoitetta tuottaa vieruspariin sopiva jälkijäsen

3. Arviot kokousten osallistujien kielitaidosta perustuvat videoihin, haastatteluihin ja etnografiseen tietoon, jota tutkijoille on kertynyt esimerkiksi aineistonhankinnan yhteydessä. Esimerkeissä esiintyvistä henkilöistä on tutkimuksen osana haastateltu Jelenaa, Olgaa, Katjaa, Ristoa ja Jenniä.

4. Lisäksi esimerkeissä esiintyvistä suomea toisena kielenä puhuvista työntekijöistä Jelena (esim. 1) ja Olga (esim. 3-4) asemoivat kokousaineiston tallentamisen yhteydessä tehdyissä haastatteluissa itse itsensä kakkoskielisiksi korostamalla muun muassa suomen puhumisen haastavuutta. 
kutsutaan ehdolliseksi relevanssiksi (ks. esim. Schegloff 1968; Heritage 1996 [1984]: 244). Jos jälkijäsen puuttuu tai on vääränlainen, keskustelukumppani on selontekovelvollisuuden alainen; toisin sanoen keskustelijat suhtautuvat vierusparirakenteeseen toiminnan normatiivisena viitekehyksenä (Heritage mts. 241-242). Esimerkiksi kysymyksen esittäminen tekee vastauksesta ehdollisesti relevantin (Schegloff \& Sacks 1973). Vastauksen sijasta keskustelukumppani voi tuottaa myös muunlaisen responssin, kunhan siinä otetaan huomioon, mikä on odotuksenmukainen vastaus - esimerkiksi tarjoamalla selityksen vastauksen puuttumiselle (Heritage mts. 245-246). Toiminnan lisäksi etujäsen asettaa odotuksia myös jälkijäsenen kielelliselle muotoilulle. Esimerkiksi vaihtoehtokysymyksen odotuksenmukainen responssi, myöntävä tai kieltävä vastaus, ilmaistaan suomen kielessä yleensä partikkelin avulla tai verbin toistolla (Sorjonen 2001b). Vuoroa, joka täyttää edellisen vuoron asettamat toiminnalliset ja muodolliset odotukset, voidaan pitää samanlinjaisena edellisen vuoron kanssa. Samaan linjaan asettuva vuoro siis edistää edellisen vuoron projisoimaa toimintaa tai sekvenssiä, hyväksyy tämän toiminnan edellyttämät vuorovaikutusroolit sekä toiminnan taustalla vaikuttavat oletukset ja vastaa edeltävän vuoron asettamiin muotoa koskeviin odotuksiin (Stivers, Mondada \& Steensig 2011: 21; Steensig 2013; kokousvuorovaikutuksessa Asmuß \& Oshima 2012). ${ }^{5}$

Tietyn vuoron saman- tai erilinjaisuuden määrittämiseksi ei aina riitä se, että tarkastelee vain edeltävää vuoroa, vaan sekvenssiä on lähestyttävä laajemmasta näkökulmasta. Laajemman kontekstin tarkastelu paljastaa, mikä kunkin vuoron edustama toiminto on ja mitä sillä haetaan juuri kyseisessä tilanteessa. Esimerkiksi vastauksen rakenteen ratkaisevat lopulta kysymykseen sisältyvät lisäoletukset ja kysymyksen sekventiaalinen asema eli sen paikka puhejaksossa (Hakulinen 2016: 136). Olennaista on, mitä kysymyksellä haetaan. Esimerkiksi kysymyssanan sisältävät tiedonhakukysymykset jakautuvat tarkennus- ja kertomiskysymyksiin, jotka luovat odotuksia erilaisille vastauksille: edellisiin riittää vastaukseksi yksittäinen informaatio, kun taas jälkimmäisillä haetaan laajempia vastauksia (Thompson, Fox \& Couper-Kuhlen 2015: 20). Myös edellä mainitulla vaihtoehtokysymyksellä voi tehdä paljon muutakin kuin hakea kyllä- tai ei-vastausta: sillä voi esimerkiksi ilmaista yllättyneisyyttä tai tarjota uutta topiikkia, jolloin pelkkä myöntävä tai kieltävä vastaus ei välttämättä riitä muodostamaan samanlinjaista responssia, vaan vastaajalta odotetaan enemmän (Steensig \& Heinemann 2013; Bolden 2016). ${ }^{6}$

Linjaan asettuminen ei ole myöskään polaarinen ilmiö: vuoro ei aina ole selvästi saman- tai erilinjainen edeltävän vuoron kanssa, vaan se voi olla myös osittain samanlinjainen tai ilmaista sitoutumattomuutta edeltävään vuoroon nähden (Niemi 2015: 19). Yhtenä esimerkkinä osittain linjaan asettuvista vuoroista voidaan pitää niin sanottuja

5. Samanlinjaisuuden eli linjaan asettumisen käsite on osin päällekkäinen prefeenssijäsennyksen kanssa; eroa selventää Niemi 2015: 17-19.

6. Vielä laveammassa tulkinnassa saman- ja erilinjaisuuden käsitteitä on pidetty eräänlaisina topiikin (Stivers 2008) tai näkökulman (Mikkola 2014b) jatkuvuuden arvioinnin välineinä. Esimerkiksi Mikkola (ma.) käsittelee erilinjaisuutta kehityskeskusteluissa työntekijän tapana ohjata vuorovaikutusta tiettyyn suuntaan. Mikkola pitää työntekijän vuoroja saman- tai erilinjaisina sen mukaan, jatkavatko ne asian käsittelyä samasta vai eri näkökulmasta kuin esimiehen edeltävä vuoro. 
muutoksia aiheuttavia vastauksia, joiden avulla vastaajat jälkikäteen muokkaavat heille esitettyä kysymystä (transformative answers, Stivers \& Hayashi 2010). Ne osoittavat vastaajan asettuvan vain osittain yhteistyöhön kysyjän kanssa: hän kyllä vastaa kysymykseen mutta samalla vastustaa jollain tavalla kysymyksen taustaoletuksia, ehtoja tai kysyjän tavoitteita (mas. 20).

Erilinjaisuutta on edellä esitellyssä kirjallisuudessa käsitelty lähinnä ykköskielisten keskinäisissä keskusteluissa, eikä erilinjaisuus ilmiönä lähtökohtaisesti liitykään osallistujien mahdollisesti puutteelliseen kielitaitoon, vaan se voi olla strateginen osa keskustelua (ks. esim. Mikkola 2014b; Stivers 2008): sillä esimerkiksi vastustetaan edellisen vuoron projisoimaa keskustelun suuntaa. Vaikka ykkös- ja kakkoskielisten puhujien vuorovaikutustoiminta noudattaa pitkälti samoja säännönmukaisuuksia, on kuitenkin perusteltua tutkia erikseen, miten erilinjaisuus ilmenee kakkoskielisissä keskusteluissa. Ensinnäkin erilinjaisuudet saattavat toisinaan olla merkki ymmärtämisen ongelmista (ks. esim. Kurhila \& Lindholm 2016: 272). Lisäksi kakkoskielisten puhujien voi rajallisten resurssien vuoksi joskus olla vaikea tuottaa vuoroja, jotka vastaisivat edeltävän vuoron asettamiin rakenteellisiin vaatimuksiin; tuottamisen ongelmat voivat siis näkyä erilinjaisina tai sellaisiksi tulkittuina vuoroina. Olisikin melko odotuksenmukaista, että erilinjaisia vuoroja esiintyisi suhteellisesti hieman enemmän kakkoskielisissä kuin ykköskielisissä keskusteluissa.

Kokousvuorovaikutuksessa saman- ja erilinjaisuus kytkeytyvät myös tilanteen institutionaaliseen luonteeseen. Osallistujiin kohdistuvat toiminnalliset ja muodolliset odotukset eivät riipu ainoastaan edeltävistä vuoroista vaan pitkälti myös heidän institutionaalisista rooleistaan. Rooleihin ja niihin sisältyviin vastuualueisiin sekä työtehtäviin liittyy erilaisia episteemisiä ja deonttisia asemia (ks. esim. Stevanovic \& Peräkylä 2012), jotka vaikuttavat siihen, millaista osallistumista työntekijältä odotetaan; toisaalta osallistujien roolit ovat myös jatkuvan neuvottelun kohteena kokouksen aikana (ks. myös esim. Asmuß \& Oshima 2012). Tällaisten odotusten tunnistamista voivat kakkoskielisten työntekijöiden kohdalla vaikeuttaa kielitaidon puutteet. Lisäksi vapaamuotoiset kokoukset, joita aineistomme edustaa, ovat tässä suhteessa heille todennäköisesti haastavampia kuin muodolliset kokoukset, joissa osallistumisen säätely ja osallistujien roolit ovat usein eksplisiittisempiä ja staattisempia.

Olemme tässä artikkelissa rajanneet tutkittavan ilmiön seuraavasti: analysoimme kakkoskielisten puhujien responsiivisessa asemassa, esimerkiksi kysymyksen tai kehotuksen jälkeen, tuottamia vuoroja, jotka eivät edistä edellisen vuoron projisoimaa toimintaa. Näitä vuoroja seuraa jonkinlainen vuorovaikutuksen progressiivisuuden tai sujuvuuden (Stivers \& Robinson 2006) ongelma: toimintasekvenssi joko pitkittyy (esim. erilaisten korjausaloitteiden tai korjausten vuoksi) tai keskeytyy kokonaan. Olemme jakaneet tutkimamme erilinjaiset vuorot kolmeen kategoriaan. Aloitamme tarkastelemalla luvussa 4 vuoroja, jotka eivät edusta etujäsenen projisoimaa toimintoa vaan tekevät tunnistettavasti jotain muuta. Toiseksi analysoimme luvussa 5 vuoroja, joiden edustama toiminto jää osallistujille epäselväksi. Lopuksi, luvussa 6, tutkimme vuoroja, jotka edustavat etujäsenen projisoimaa toimintoa vain osittain eli eivät täysin asetu linjaan edeltävän vuoron kanssa. 


\section{Responsiivinen vuoro ei edusta projisoitua toimintoa}

Ensimmäinen esimerkki on kokouksesta, johon osallistuvat säätiön työntekijöistä Risto ja Katja sekä säätiön ulkopuolinen, suomea toisena kielenä puhuva Georgi. Kokouksen tavoitteena on pohtia, olisiko säätiön kannattavaa hakea erästä projektirahoitusta. Mikäli rahoitusta ryhdytään hakemaan, Georgi on tarjolla projektin vetäjäksi, joten kokousasetelmassa on myös työhönottohaastattelun piirteitä (ks. esim. Kirilova 2013). Tämä näkyy seuraavassa katkelmassa niin, että säätiön esimies Risto toimii siinä ikään kuin haastattelijana ja Georgi vastaa kysymyksiin työnhakijan roolissa. Esimerkki 1 on kokouksen alusta, jossa puhutaan Georgin taustasta ja työkokemuksesta. Erilinjaiseksi tulkitsemamme vuoro on rivin 5 dialogipartikkeli.

(1) Projektipäällikkö

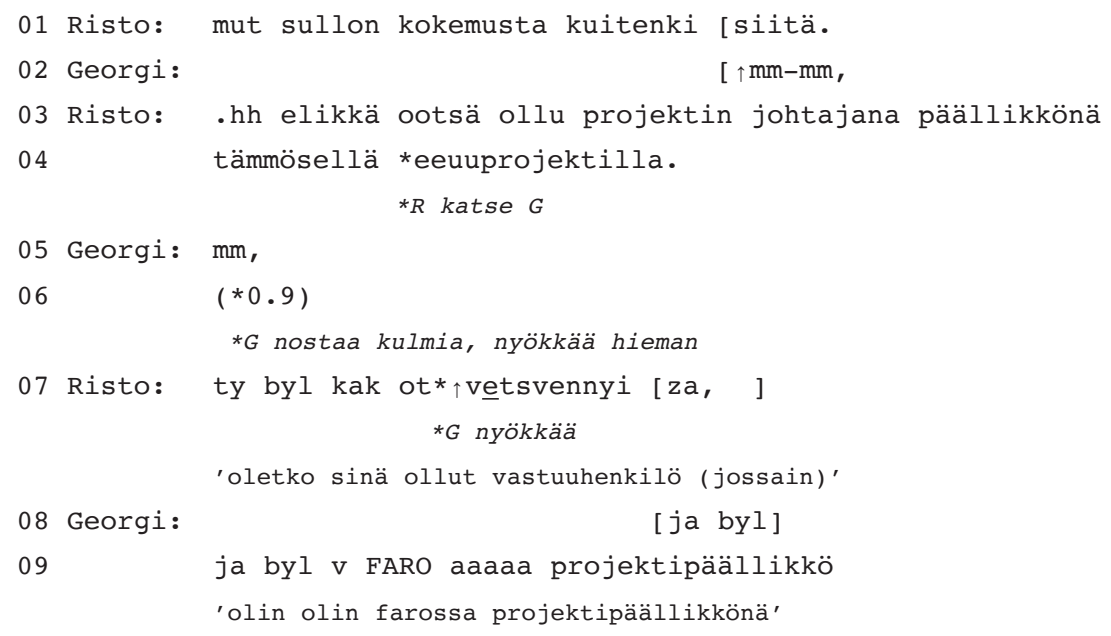

Juuri ennen katkelmaa puheena on ollut Georgin englannin kielen taito ja Georgi on pohdiskellut monisanaisesti omaa englannin kielen taitoaan suhteessa mahdollisiin tuleviin työtehtäviin. Katkelma alkaa tilanteesta, jossa Risto yhteenvedonomaisesti tarkistaa deklaratiivilauseella mut sullon kokemusta kuitenki siitä (r. 1) Georgin kokemuksen englannin kielellä työskentelystä. Georgi ottaa Riston vuoron vastaan tuottamalla laskevalla intonaatiolla partikkelin $m m-m m$ (r. 2), mikä ilmaisee, että hänellä ei ole tähän topiikkiin lisättävää (acknowledger, Gardner 2001: 250).?

Tämän jälkeen Risto kysyy Georgin aiemmasta johtajakokemuksesta vaihtoehtokysymyksellä elikkä ootsä ollu projektin johtajana päällikkönä tämmösellä eeuuprojektilla (r. 3-4). Kysymyksen aikana Risto, joka on tätä ennen katsonut eteensä, kääntää katseensa Georgiin, mikä korostaa Riston odottavan Georgilta vastausta. Odotuksenmukainen myöntävä vastaus suomenkieliseen vaihtoehtokysymykseen

7. Gardner (2001: 198) mainitsee intonaatioltaan samanlaisen, korkealta alkavan ja laskevan mmpartikkelin minimaalisena responssina kysymykseen. 
on joko verbin toistaminen (mikäli kysymys tulkitaan puhtaasti tietoa hakevaksi) tai partikkeli joo (mikäli kysyjä pikemminkin hakee tiedolle vahvistusta) (Sorjonen 2001b). Toisaalta koska keskustelu muistuttaa tässä kohden työhaastattelua, voi myös olla, että Risto ei hae kysymyksellään ainoastaan vahvistusta siihen, että Georgi on toiminut projektipäällikkönä, vaan myös lisätietoja tämän työkokemuksesta. Kun työhaastattelussa kysytään aiempaa työkokemusta, on tyypillistä, että hakija vastaa jonkinlaisella narratiivilla (Kirilova 2013: 130): kuvaus aiemmasta työkokemuksesta antaa hakijalle mahdollisuuden esitellä osaamistaan ja haastattelijalle tilaisuuden tehdä päätelmiä tämän sopivuudesta tehtävään. Kyseessä on siis Steensigin ja Heinemannin (2013) termein kyllä/ei+-kysymys eli vaihtoehtokysymys, johon vastaaminen tyydyttävästi vaatii paitsi kiellon tai myönnön myös jonkinlaista lisätietoa. ${ }^{8}$

Georgi ei kuitenkaan anna sen enempää selkeää myöntävää vastausta kuin lisätietojakaan vaan esittää ongelmalliseksi osoittautuvan $m m$-dialogipartikkelin (r. 5). Vuoro muistuttaa hänen edeltävää vuoroaan (r. 2), mutta siinä missä tämä edeltävä vuoro alkaa melko korkealta ja laskee hieman loppua kohti, fokusvuoron $m m$ (r. 5) on tasaisempi, ja se kuulostaa niin sanotulta jatkajalta (continuer, Gardner 2001: 117; suomessa Sorjonen 2001a: 303; Routarinne \& Ogden 2005: 168), jonka funktio on ilmaista edellinen vuoro vastaanotetuksi ja kehottaa puhujaa jatkamaan. Tätä Georgin vuoroa seuraa lähes sekunnin tauko, jonka aikana sekä Risto että Georgi katsovat toisiaan.

Georgi reagoi tilanteen mahdolliseen ongelmallisuuteen nostamalla kulmakarvojaan lähes samanaikaisesti, kun Risto ottaa puheenvuoron (r. 7). Riston vuoro on paljastava: hän vaihtaa kielen venäjään ja toistaa jo esittämänsä kysymyksen oleellisilta osin samanlaisena kuin edellä suomeksi. Vuoro osoittaa, että Risto on tulkinnut Georgin edeltävä vuoron (r. 5) ja kysymykseen vastaamattomuuden kertovan kielellisistä ongelmista. Ongelmien ratkaisuksi Risto vaihtaa kielen Georgin ensikieleen. Pelkkä jatkoa pyytävä partikkeli ei siis tilanteessa ole vastannut aiemman keskustelun herättämiä odotuksia.

Tilanteen jatkon perusteella voi arvioida, että Riston tulkinta Georgin ymmärrysongelmasta on ainakin osittain oikea. Risto ei ehdi esittää alkuperäistä kysymystään (r. 7) kokonaan uudelleen venäjäksi ennen kuin Georgi jo vastaa. Vastaus ajoittuu heti sen perään, kun Riston venäjänkielinen vuoro paljastuu kysymykseksi: venäjässä väitelauseen erottaa vaihtoehtokysymyksestä vain nouseva intonaatio (esim. Bolden 2016: 41-42), joka sijoittuu tässä otvetsvennyi-sanaan ('vastuuhenkilö'). Georgin voi siis päätellä ymmärtäneen suomenkielisenkin kysymyksen sisällön muttei sen edustamaa toimintoa. Riston kielenvaihdon jälkeen Georgi vastaa myöntävästi alkuperäiseen kysymykseen ja kehittelee vastausta odotuksenmukaisella tavalla antamalla yksityiskohtaista tietoa aiemmasta työkokemuksestaan (r. 8-9). Georgin vuorossa on kiinnostavaa myös se, että hän ei vastaa responssipartikkelilla vaan toistamalla kysymyksen keskeisen elementin. Boldenin (2016: 49-51) mukaan tämä tarkoittaa venäjänkielisessä keskustelussa sitä, että vastauksen pitäisi jo olla pääteltävissä edellä sanotusta ja kysymystä käsitellään siksi episteemisestä näkökulmasta tilanteeseen sopimattomana.

8. Kyseinen esimerkki vastaa Steensigin ja Heinemannin luokittelussa tapauksia, joissa kysymykseen sisältyy vaatimus tarkennuksesta (specification requests for telling, mas. 224-226). 
Georgin käsitys vastauksen pääteltävyydestä tukee selitystä, jonka mukaan hän ei ole tulkinnut Riston vuoroa alun perin kysymykseksi.

Esimerkin 1 erilinjaisella vuorolla ei ole suuria vaikutuksia kokouksen kulkuun: erilinjainen vuoro selvitetään nopealla kielenvaihdolla niin, että vuorovaikutuksen toimintalinja ei katkea. Seuraavaksi esittelemämme esimerkki on tässä mielessä toisenlainen, vaikka siinäkin kyse on kakkoskielisen tuottamasta vuorosta (tai oikeastaan jaksosta), joka ei edusta projisoitua toimintoa. Esimerkissä 2 erilinjainen vuoro (r. 1921) vie nimittäin koko keskustelun eri suuntaan kuin mitä sitä edeltävän toiminnan perusteella olisi voinut ennustaa. Kakkoskieliselle työntekijälle (Jelena) tarjotaan katkelman alussa mahdollisuus kokemusten esittelyyn, mutta hänen vuoronsa aloittaa kokonaan uuden topiikin. Katkelma on kokouksesta, jossa säätiön työntekijät (Risto, Katja ja Jelena) tapaavat museoyhteistyökumppanin edustajia (Ulla ja Sari) puhuakseen juuri päättyneestä yhteistyöstä ja suunnitellakseen mahdollisia tulevia yhteistyöhankkeita. Jelena on ollut säätiön puolesta vastuussa yhteistyöhankkeen käytännön järjestelyistä, ja hän on säätiön työntekijöistä se, joka tuntee hankkeen toteutuksen parhaiten. Tapaaminen alkaa useamman minuutin jutustelulla (ei litteraatissa), jonka jälkeen Ulla siirtää puheen kokouksen varsinaiseen agendaan (r. 1).

(2) Yhteistyöprojekti

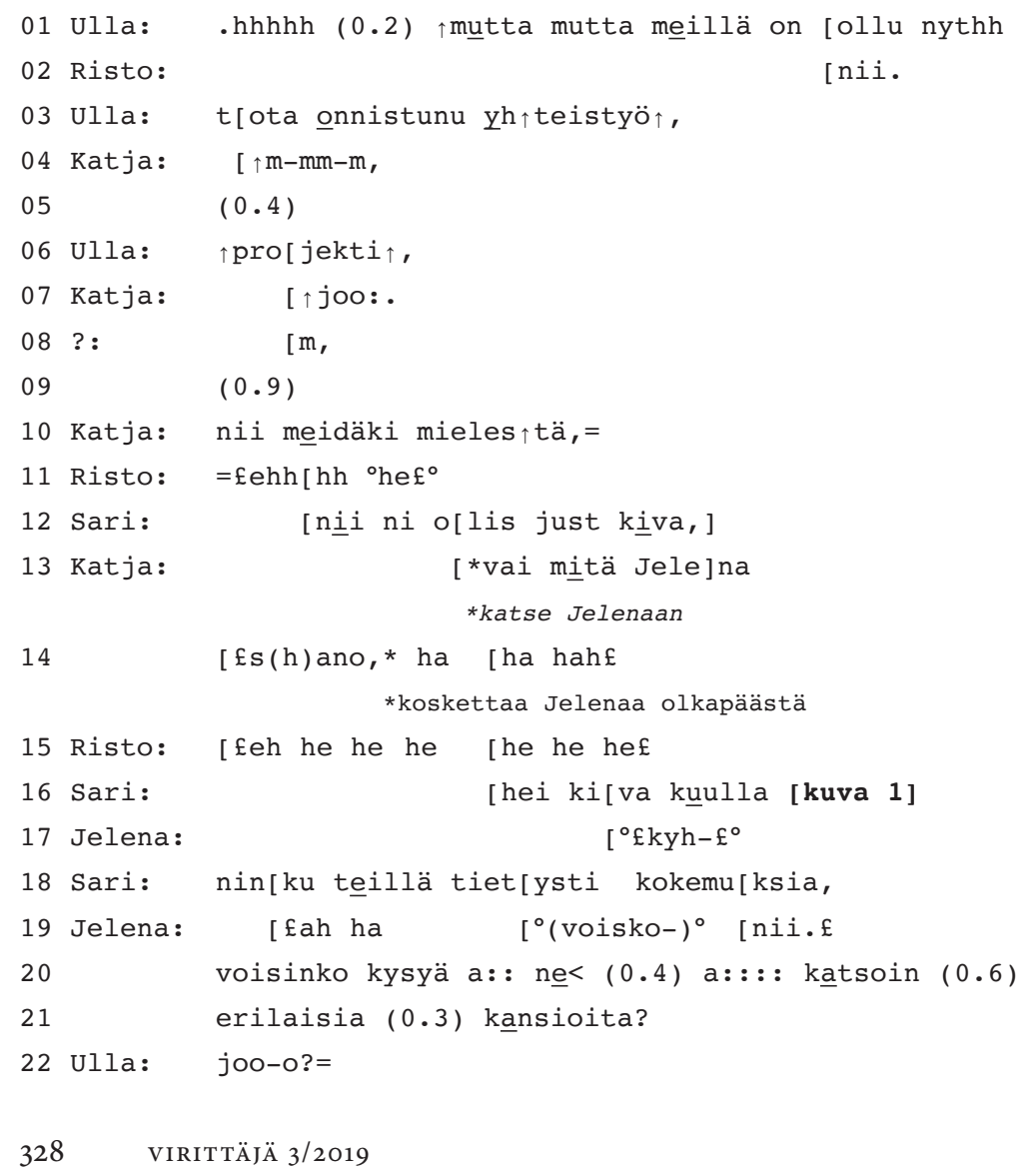




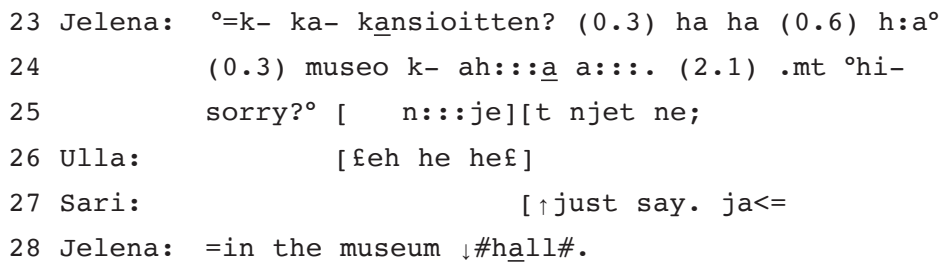

Ullan vuoro esimerkin alussa (r. 1, 3) tuo kokouksen yhden varsinaisen aiheen keskustelun topiikiksi: hän evaluoi säätiön ja museon jo toteutuneen yhteistyön onnistuneeksi. Ullan vuoroa säestävät Riston ja Katjan hyväksyvät dialogipartikkelit (r. 2, 4), jotka ikään kuin ratifioivat siirtymisen kokouksen agendaan. Lyhyen tauon jälkeen Ulla täydentää vielä edellistä vuoroaan NP:llä projekti (r. 6, ns. increment, Couper-Kuhlen \& Ono 2007). Koska hän arvioi asiaa, johon muillakin osallistujilla on pääsy, hänen vuoronsa tekee relevantiksi niin sanotun toisen arvioinnin (second assessment, Pomerantz 1984: 61). Katja aloittaakin oman evaluaationsa päällekkäispuhuntana myöntävällä partikkelilla joo (r. 7) ja eksplikoimalla tauon jälkeen säätiön työntekijöiden mielipiteen nii meidäki mielestä (r. 10). Käyttämällä monikon 1. persoonan pronominia Katja tuo näkyviin kokouksen osallistujien jakautumisen kahteen tiimiin (Djordjilovic 2012), säätiön työntekijöihin ja museon edustajiin, joilla molemmilla on oma näkökulmansa yhteistyön arvioimiseen.

Tätä seuraa jakso (r. 12-18), jossa Jelenaa kutsutaan yhdessä sekä kielellisin että kehollisin keinoin ottamaan seuraava puheenvuoro. Ensinnäkin Katja siirtää oman kannanottonsa jälkeen sanallisesti puheenvuoron Jelenalle kysymällä vai mitä Jelena $s(h) a n o$ (r. 13-14). Samalla Katja kääntää katseensa Jelenaa kohti ja koskettaa tämän olkapäätä. Katja esittää siis kannanoton mutta osoittaa samalla, että hänen pääsynsä kyseiseen tietoon on jollakin tavalla rajallinen (downgraded [first] assessments, Heritage \& Raymond 2005: 19-21). Vaikka säätiön työntekijät muodostavat tiimin ja siten jakavat selontekovelvollisuuden (Djordjilovic 2012), Katja osoittaa, että nimenomaan Jelenalla on arvioitavan asian suhteen korkea episteeminen status (Heritage 2012). Katjan lisäksi Sari (r. 12, 16, 18) kehottaa säätiön edustajia jakamaan heidän puolensa kokemuksia. Sari osoittaa puheensa kielellisin perustein yhtä lailla Ristolle, Katjalle ja Jelenalle (pronomini teillä r. 18), mutta hänen katseensa on pääosin kohdistunut Jelenaan. Jo Sarin vuoron alussa (r. 16) kaikkien muidenkin katse on suuntautuneena Jelenaan (kuva 1 s. 330). Jelenaa siis monin tavoin velvoitetaan osallistumaan yhteistyöhankkeen arviointiin. Niinpä tilanteessa olisi odotuksenmukaista, että Jelena vastaisi kertomalla kokemuksistaan.

Näin ei kuitenkaan tapahdu, sillä Jelena ei tartu tarjottuun tehtävään vaan aloittaa temaattisen sivupolun (r. 19). Hän pyytää ensin lupaa kysyä ja melko hitaasti esitetyssä vuorossa nostaa topiikiksi museon aulassa olleet kansiot. Ulla kehottaa nousevalla intonaatiolla tuotetulla joo-partikkelilla (r. 22) Jelenaa jatkamaan, ja Jelena saa vasta kielenvaihdon jälkeen selitettyä, mitä kansioita hän tarkoittaa. Jelenan selitystä seuraa topiikin vaihtuminen: osallistujat siirtyvät puhumaan kansioista. Jelena ei siis osoita tunnistaneensa, että muut odottavat hänen yhtyvän yhteistyön positiiviseen evaluointiin, ja yhteistyöstä saatuihin kokemuksiin palataan uudestaan vasta noin kymmenen minuutin kuluttua. 


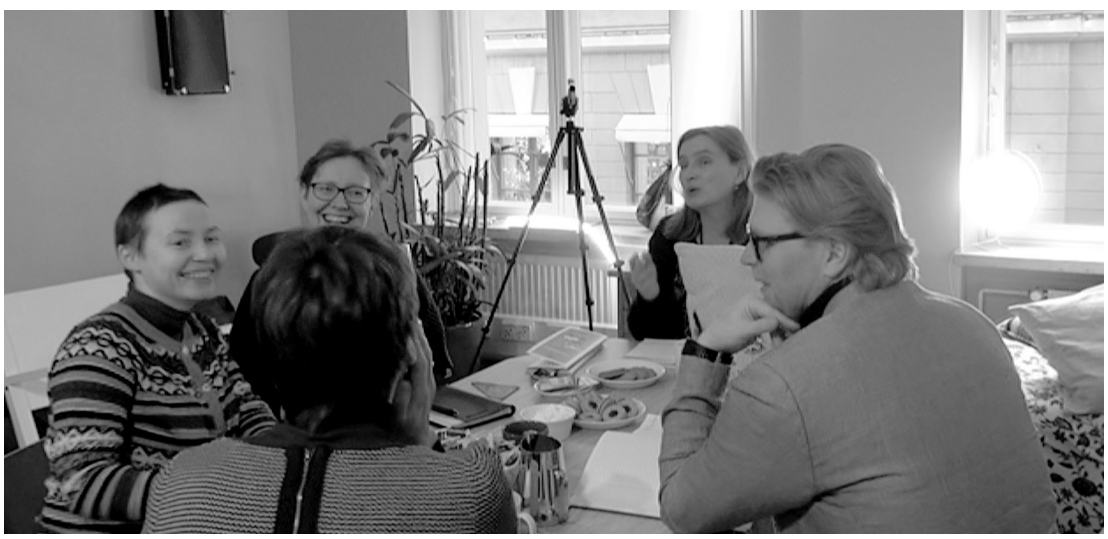

Kuva 1.

Kokoustilanne (Jelena etualalla selkä kameraan päin, muut vasemmalta oikealle: Katja, Sari, Ulla, Risto).

Jelenan aloittama sivupolku vaikuttaa edellisen esimerkin tapaan ymmärtämisen ongelmalta. Hän ei kerro kokemuksistaan mutta ei myöskään tarjoa selitystä sille, miksi hän ei tee niin; hän ei siis suuntaudu millään tavoin kokemuksista kertomisen relevanssiin tässä tilanteessa (ks. esim. Heritage 1996 [1984]: 245-246). Sen lisäksi, että hänen vuoronsa ei vastaa edeltävien vuorojen asettamiin odotuksiin, hänen tekemänsä topiikinvaihto on varsin epätyypillinen. Ensinnäkin puhujat pyrkivät yleensä sitomaan uudet topiikit edeltävään puheeseen (esim. Schegloff \& Sacks 1973: 305). Tästä Jelenan vuorossa ei ole viitteitä, vaan kyseessä on niin sanottu disjunktiivinen topiikinvaihto (Maynard 1980). Uuden topiikin aloittavat vuorot sijoittuvat useimmiten sellaisiin kohtiin, joissa edeltävä puhe on saavuttanut tunnistettavan lopun (Schegloff \& Sacks 1973). Jelenan vuoro sen sijaan sijoittuu kohtaan, jossa ollaan nimenomaan aloittamassa uutta, kokouksen agendan ensimmäistä topiikkia eli yhteistyön arviointia. Vaikka Jelenan vuoro ei suoraan osoita, ettei hän ole ymmärtänyt edeltäviä vuoroja, voidaan ainakin todeta, että hän ei osoita hahmottaneensa keskustelun sekventiaalista rakennetta ja edeltävän puheen asettamia odotuksia ja rajoituksia.

Jelenan vuoron toiminnalliseen ja topikaaliseen erilinjaisuuteen ei kuitenkaan puututa, vaikka sen voi katsoa hidastavan kokousta. Yhtenä syynä voi olla, että hänen vuoronsa tulkitseminen sen paremmin relevantiksi kuin epärelevantiksi ei ole aluksi helppoa. Jo vuorossa itsessään on tekijöitä, joiden takia sitä on hankala tulkita: taukoja, oikean muodon haku, naurua ja kielenvaihtoja. Myös muut keskustelijat orientoituvat Jelenan tuotto-ongelmien ratkaisuun: Ulla ensin kehottaa joo-partikkelilla (r. 22) Jelenaa jatkamaan ja sitten naurahtaa Jelenan "kanssa" (r. 26); Sari puolestaan rohkaisee Jelenaa kielenvaihtoon (r. 27), jonka Jelena on jo aloittanut (r. 25). Kun Jelenan esiin nostama uusi topiikki on vielä sinänsä kokouksessa relevantti, itse topiikin vaihdoksen ongelmallisuutta ei käsitellä eksplisiittisesti vuorovaikutuksessa. Lisäksi on muutenkin tavallista, että ensikieliset osallistujat eivät nosta esiin kakkoskielisten puheeseen liittyviä ongelmia institutionaalisessa kontekstissa (Kurhila 2006; Firth 2009).

Esimerkeissä 1-2 esitetyt katkelmat eroavat toisistaan vuorovaikutuksen kokonaissujuvuuden kannalta. Niille on kuitenkin yhteistä se, ettei kakkoskielisen osallistujan 
vuoro kummassakaan tapauksessa vastaa edeltävän vuoron tai toimintajakson sille asettamiin odotuksiin. Seuraavassa luvussa tarkastelemme hieman toisenlaisia tapauksia: kakkoskielisen tuottamia vuoroja, jotka ovat linjaukseltaan epäselviä.

\section{Responsiivisen vuoron edustama toiminto on epäselvä}

Useimmiten keskustelun osallistujat pystyvät tulkitsemaan niin saman- kuin erilinjaiset vuorot, ja he voivat joko palauttaa keskustelun alkuperäiselle linjalle (esim. 1) tai lähteä seuraamaan erilinjaisen vuoron tarjoamaa vaihtoehtoista suuntaa (esim. 2). Toisinaan responsiivinen vuoro voi kuitenkin olla - vaikkakin kielellisesti ymmärrettävä - linjaukseltaan epäselvä siten, että osallistujat eivät osaa tulkita sitä osaksi meneillään olevaa keskustelua. Seuraava esimerkki on kokouksesta, jossa suunnitellaan järjesteillä olevan tapahtuman tiedotusta. Kokouksen kieleksi on sovittu suomi, sillä yksi osallistujista ei osaa venäjää (ks. kielisopimuksista Eskildsen \& Theodórsdóttir 2017). Kokouksen tässä vaiheessa käsitellään venäjänkielistä tiedotusta, josta päävastuussa on suomea toisena kielenä puhuva säätiön työntekijä Olga. Osallistujat ovat esimerkin tilanteessa tekemässä ehdotuksia mahdollisista venäjänkielisistä viestintäkanavista. Kuten Jelena esimerkissä 2 Olga on tässä katkelmassa se, jolla on ammatillisen roolinsa puolesta erityisasema aiheen käsittelyssä. Riitta, ulkopuolinen asiantuntija, on juuri maininnut Suomessa toimivan venäjänkielisen radiokanavan Sputnikin, jolloin Olga on näyttänyt epäröivältä - toistaen ehdotuksen päätään keikutellen - ja säätiön esimies Risto on todennut, että radioasema soittaa pelkästään musiikkia. Katkelman alussa Riitta jatkaa perustelemalla omaa ehdotustaan tarkemmin. Erilinjaisen vuoron esittää Olga (r. 6).

(3) Valitettavasti ei

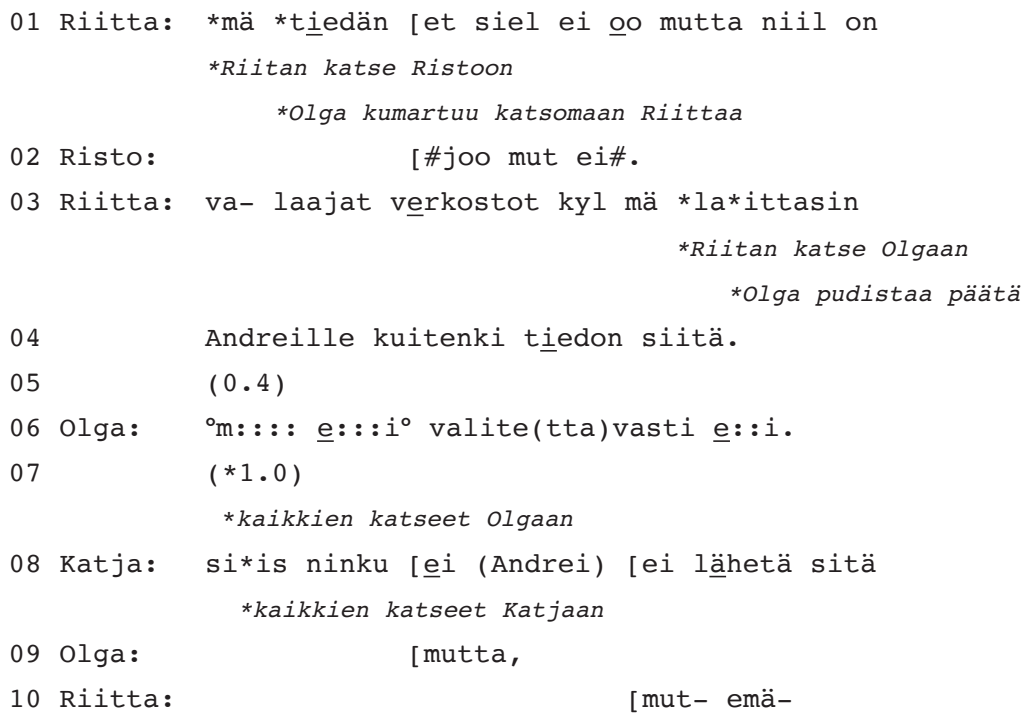




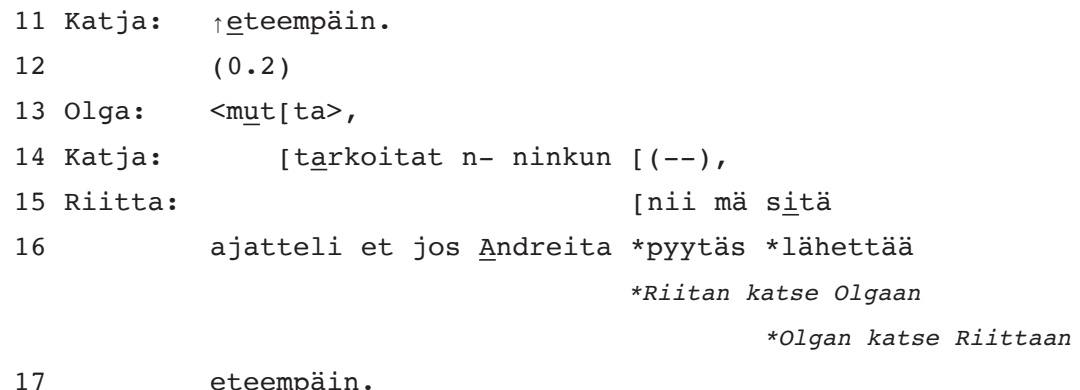

Riitta perustelee ehdotustaan sillä, että radiokanavan väellä on laajat verkostot (r. 1, 3). Hänen katseensa on Ristossa, jonka kommenttiin hänen perustelunsa pyrkii vastaamaan. Tämän jälkeen Riitta tarkentaa aiempaa ehdotustaan: radiokanavan toimittajalle kannattaisi lähettää tiedote tapahtumasta (r. 3-4). Ehdotuksen alkupuolella Riitta siirtää katseensa Ristosta Olgaan. Olgalla on Stevanovicin ja Peräkylän (2012) termein tässä tilanteessa enemmän deonttista auktoriteettia kuin pelkän työntekijäaseman perusteella (johtaja vs. alainen) voisi päätellä, sillä suunnitteilla olevan tapahtuman venäjänkielinen tiedotus on hänen vastuullaan. Vuorovaikutuksessa myös orientoidutaan tähän auktoriteettiin esimerkiksi niin, että Riitan ehdotus on selvästi suunnattu Olgalle. Samanlinjainen responssi tämäntyyppiseen tulevaa toimintaa koskevaan ehdotukseen olisi joko ehdotuksen hyväksyminen tai torjunta (mas. 300). Näistä kahdesta torjunta olisi preferoimaton vaihtoehto, jolloin siihen todennäköisesti liittyisi myönnytteleviä elementtejä tai perustelu sille, miksi ehdotus torjutaan (ks. esim. Pomerantz \& Heritage 2013: 210).

Olga pystyy tulkitsemaan tilanteen asettamat odotukset paremmin kuin Jelena esimerkissä 2: hän tuottaa vastauksen ehdotukseen sekä kehollisesti (pään pudistus r. 3) että verbaalisesti (r. 6). Vastaus hahmottuu torjunnaksi, mutta sen suhde aiempaan keskusteluun ei ole ongelmaton. Olga on nojautunut eteenpäin katsomaan Riittaa jo aiemmin (r. 1) ja reagoi Riitan katseen kääntymiseen alkamalla pudistella päätään (r. 3). Lyhyen tauon (r. 5) jälkeen Olga esittää ongelmalliseksi osoittautuvan responsiivisen vuoron (r. 6). Vuoron alussa on epäröintiä ja venyttäen lausuttu kieltosana ja tämän jälkeen adverbilla valitettavasti täydennetty uusi kielto. Olgan vuoroa seuraa pitkä tauko (r. 7), jonka aikana kaikkien katseet ovat suuntautuneet häneen. Olga puolestaan katsoo Riittaa osoittamatta kehollisesti, että olisi elaboroimassa vuoroaan pidemmälle. Taukoa seuraavissa vuoroissa sekä Katja että Riitta käsittelevät Olgan vuoroa ongelmallisena. Ensin Katja tekee korjausaloitteen, jolla hän pyrkii selvittämään, mitä Olga on tarkoittanut eli mikä on Olgan vuorossaan esittämän kiellon suhde edeltävään keskusteluun (r. 8, 11). Katjan korjausaloite on ymmärrysehdokas (ks. Kurhila 2006: luku 5), eli hän esittää yhden mahdollisen tulkinnan Olgan vuorosta. Enemmän tai vähemmän päällekkäin Katjan vuoron kanssa sekä Olga (r. 9, 13) että Riitta (r. 10) kilpailevat vuorosta. Olga ei saa tässä vaiheessa mahdollisuutta vastata tai täydentää omaa kantaansa, vaan Riitta ottaa pidemmän vuoron ja avaa omaa aiempaa ehdotustaan (r. 15-17). Tämän tarkennuksen aikana Riitta kääntää uudelleen katseen Olgaan. 
Olgan vuoron (r. 6) epäselvyys kumpuaa monista lähteistä. Osasyynsä on varmasti kiellon kategorisuudella (myönnyttelyn puute) ja perustelujen puuttumisella; Olgan rooli tiedotuksen vastuuhenkilönä vahvistaa hänen selontekovelvollisuuttaan tilanteessa, jossa hän torjuu toisen asiantuntijan ehdotuksen. Myös vuoron kielellinen muotoilu jättää tulkinnan avoimeksi. Riitta on muotoillut ehdotuksensa edellä ikään kuin omasta näkökulmastaan yksikön 1. persoonassa mä laittasin. Olgan vuoron kolmaspersoonainen ei ei kohdennu suoraan Riitan ehdotuksessaan käyttämän verbin kielloksi (ks. myös Katjan reaktio r. 8). Epäselväksi jää myös, mitä valitettavasti-adverbilla pahoitellaan. Ainakaan edellisen Riitan lausuman esittämän sisällön pahoitteleminen ei ole luontevaa, sillä lausuma on esitetty Riitan omasta näkökulmasta yksikön 1. persoonassa. Kielelliset epätarkkuudet eivät välttämättä johda vuorovaikutuksen ongelmiin kakkoskielisissä keskusteluissa (Kurhila 2005), mutta tässä tapauksessa tulkinnan vaikeus näkyy kuitenkin ongelmina keskustelun etenemisessä.

Olga pyrkii siis itsekin jatkamaan puhetta (r. 9, 13). Hän käyttää molemmilla kerroilla mutta-partikkelia, mutta (ehkä päällekkäispuhunnan vuoksi) vuorot jäävät kesken. Olgan yritykset tulevat hieman myöhään, vasta Katjan ja toisella kerralla myös Riitan korjausaloitteiden alun jälkeen. Mutta-alkuinen vuoro ei myöskään kuulosta Olgan edellä esittämää kantaa valottavalta tai perustelevalta, sillä lausumapartikkelina käytetty mutta kontrastoi ilmauksen yleensä edellä olevaan lausumaan (VISK $\$ 801$ ). Näin ollen sen avulla tuotaisiin todennäköisemmin keskusteluun esimerkiksi vaihtoehtoinen ehdotus. Katja ja Riitta eivät kuitenkaan anna tilaa sen esittämiseen vaan pyrkivät ensin selvittämään epäselväksi jääneen vuoron merkityksen.

Tässä luvussa olemme esittäneet yhden esimerkin tapauksista, joissa kakkoskielisen tuottama vuoro on linjaukseltaan epäselvä. Siinä ehdotukseen reagoivan vuoron merkitys osoittautuu epäselväksi ja muut osallistujat alkavat selvittää sitä. Vuoroa käsitellään ongelmallisena mutta kuitenkin relevanttina, minkä osoittaa oikeastaan jo se, että ongelma ylipäänsä yritetään ratkaista. Esimerkki poikkeaa edellisen luvun esimerkeistä myös siinä, ettei ongelman suhde kakkoskielisyyteen ole yhtä suoraviivainen. Siinä missä esimerkeissä 1-2 kielitaito nousi esiin vuorovaikutuksen tasolla, tässä siihen ei viitata. Edellä olemme kuitenkin esittäneet, että yksi syy vuoron ongelmallisuuteen on sen epäselvyys, joka taas on yhteydessä ainakin vuoron lievään kieliopilliseen epätarkkuuteen. Toisaalta kyse voisi periaatteessa olla myös ymmärtämisen ongelmasta, mikäli Olga ei ole tunnistanut niitä Riitan ehdotuksen asettamia odotuksia, jotka kohdistuvat häneen. Vastaavaa ambivalenssia on seuraavan luvun esimerkeissä, joissa ongelmalliseksi merkityt vuorot ovat jollakin tavalla puutteellisesti linjassa edeltävien vuorojen kanssa.

\section{Responsiivinen vuoro edustaa projisoitua toimintoa vain osittain}

Edellisissä luvuissa on käsitelty selvästi erilinjaisia tai linjaukseltaan epäselviä vuoroja. Aineistossamme on myös sellaisia ongelmia aiheuttavia responsiivisia vuoroja, jotka ensi katsomalta näyttäisivät olevan linjassa etujäsenen kanssa. Lähempi tarkastelu osoittaa kuitenkin, että linjaan asettuminen on näissä tapauksissa vain osittaista 
eli responsiivinen vuoro ei kaikilta osin vastaa etujäsenen asettamiin odotuksiin. Käsittelemme seuraavaksi pitkähköä katkelmaa, jonka aikana kakkoskieliseltä puhujalta (Olga) haetaan kysymysten avulla perusteluja päätöksen tekemisen tueksi. Kakkoskielinen puhuja onnistuu kyllä muodollisesti vastaamaan kysymyksiin, mutta sekvenssin pitkittyminen osoittaa, että hänen tuottamansa vastaukset eivät tyydytä kysyjää. Katkelma on samasta kokouksesta kuin edellinen esimerkki 3 mutta hieman aikaisemmasta vaiheesta, ja pituuden vuoksi se on jaettu analyysissa kolmeen osaan. Katkelmassa Katja hakee Olgalta vastausta siihen, tarvitseeko järjestettävästä tapahtumasta laatia venäjänkielistä yleistiedotetta. Kuten edellä mainittiin, Olga on vastuussa tapahtuman venäjänkielisestä tiedotuksesta. Katja taas on vastuussa tapahtuman kokonaisuudesta, ja hän on siten myös Olgan lähin esimies; Katjalla on siis ammatillisen roolinsa puolesta oikeus kyseenalaistaa Olgan päätöksiä ja pyytää tältä perusteluja. Kokouksessa on edellä käsitelty suomenkieliseen yleistiedotteeseen liittyviä asioita, ja hetkeä ennen katkelmaa on siirrytty käsittelemään venäjänkielistä tiedotetta. Katja on jo ennen katkelman alkua esittänyt (lähinnä Olgalle suunnattuja) tiedotteen tarvetta, kohderyhmää, sisältöä ja lähetysajankohtaa koskevia kysymyksiä, joihin Olga on vastannut ja myös muut osallistujat ovat kontribuoineet jonkin verran. Seuraavan katkelma alussa (r. 1) Katja palaa kuitenkin uudelleen kysymykseen venäjänkielisen yleistiedotteen funktiosta.

(4a) Kenelle ja miksi

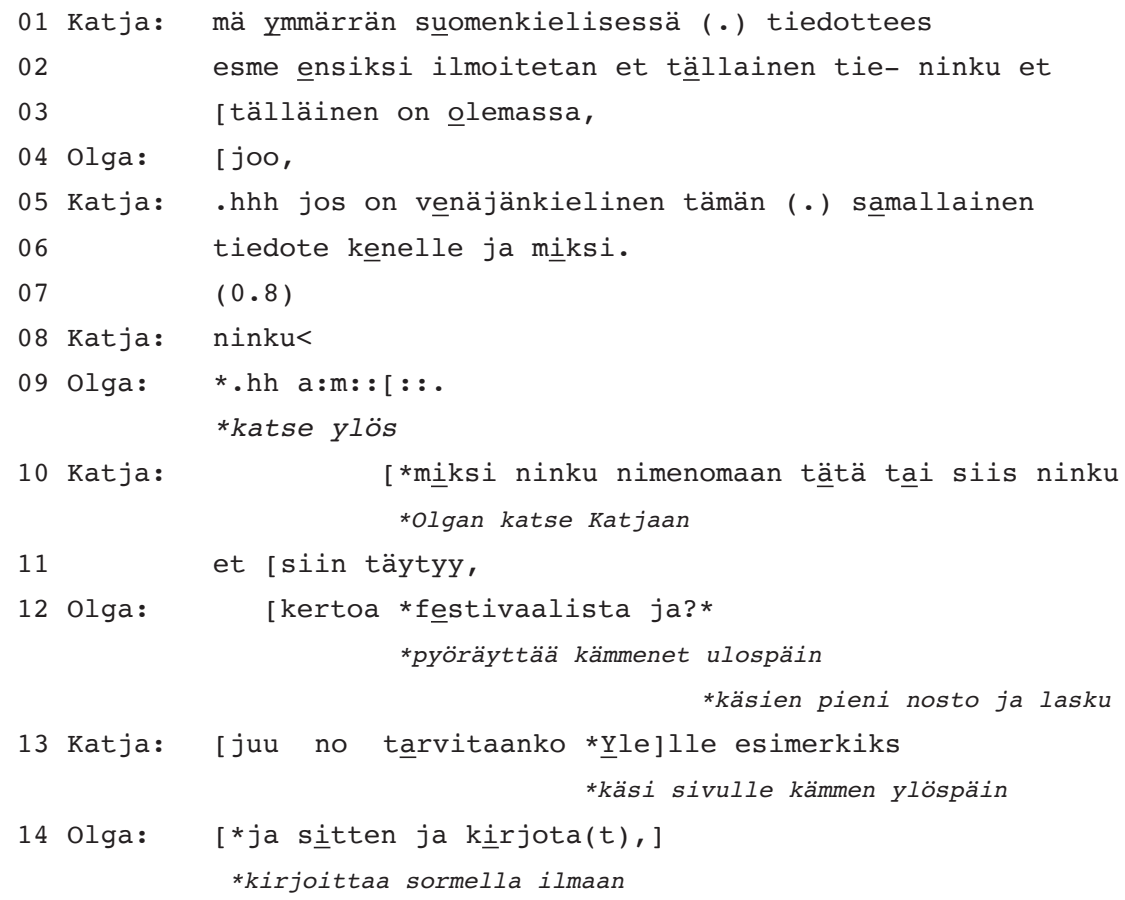


Katja aloittaa pohjustamalla tulevaa kysymystä: hän kontrastoi venäjänkielisen tiedotteen suomenkielisen tiedotteen kanssa (r. 1-3). ${ }^{9}$ Katja ilmaisee ymmärtävänsä tarpeen suomenkieliselle tiedotteelle mutta siirtyy sitten kyseenalaistamaan vastaavan venäjänkielisen tiedotteen laatimisen (r. 5-6). Konjunktio jos kertoo, että tiedotteen olemassaoloa ei vielä pidetä päätettynä vaan että se nostetaan uudelleen keskusteltavaksi. Tiedotteen tarpeellisuuden epäilyä korostaa myös se, että asia kyseenalaistetaan uudelleen huolimatta aiemmista tiedotteen tarpeellisuutta puoltavista ja sen yksityiskohtia käsittelevistä vastauksista. Kysymyksen kontrastiivinen muotoilu ja sekventiaalinen asema heijastavat siis Katjan kielteistä suhtautumista tiedotteen tarpeellisuuteen. Tämä luo myös odotuksen siitä, että jos tiedotetta pidetään edelleen tarpeellisena, sen tueksi pitää esittää uusia argumentteja. Tällä kertaa Katja tarkentaa kysymyksen kahteen kysymyssanaan, kenelle ja miksi, jotka hän esittää painokkaasti vuoron lopussa (r. 6). Hän siis hakee nimenomaan tiedotteen vastaanottajiin ja funktioon liittyviä argumentteja. Venäjänkielistä tiedotetta koskevaa miksi-kysymystä ei myöskään ole esitetty aiemmassa keskustelussa. Katjan kysymys on kohdistettu Olgalle: hänen katseensa on Olgassa, ja Olga on myös ammatillisen roolinsa puolesta vastuussa venäjänkielisestä tiedotteesta. Kysymystä seuraavat tauko (r. 7) ja Olgan epäröintiäänne (r. 9). Katja pyrkii tässä vaiheessa tarkentamaan miksi-kysymystä edelleen (r. 10-11), mutta hänen vuoronsa keskeytyy Olgan aloittaessa vastauksensa.

Olga vastaa Katjan miksi-kysymykseen hyvin yleisellä tasolla: tiedotteen tarkoitus on kertoa järjestettävästä tapahtumasta (r. 12). Edellä esitetyn pohjalta vastausta ei voi pitää täysin kontekstiin sopivana. Kaikki kokouksen osallistujat ovat myös enemmän tai vähemmän viestinnän ammattilaisia, joten kaikille on luultavasti selvää, että yleistiedote kertoo tapahtumasta. Asiaa on lisäksi käsitelty jo suomenkielisen yleistiedotteen yhteydessä. Kysymys, johon Katja hakee vastausta, koskee nimenomaan venäjänkielisen yleistiedotteen funktiota. Vastauksen pitäisi sisältää tietoa siitä, mitkä tahot hyötyisivät nimenomaan venäjänkielisestä tiedotteesta ja miksi. Olgan vastaus on siis näennäisesti linjassa Katjan kysymyksen kanssa, mutta se on sisällöltään epärelevantti tilanteen vaatimuksiin nähden (ks. myös Stivers \& Robinson 2006: 383).

Katja reagoikin Olgan vastaukseen ottamalla välittömästi vuoron uudelleen, vaikka Olgan vastauksen voi katsoa olevan vielä kesken; se päättyy ja-sanaan ja nousevaan intonaatioon. Hän kuittaa Olgan vastauksen hyvin lyhyesti juu-responssipartikkelilla ja siirtyy saman tien tarkentavaan lisäkysymykseen siitä, tarvitaanko esimerkiksi Ylelle venäjänkielinen tiedote (r. 13). Katja siis pikemminkin ohittaa Olgan vastauksen kuin ottaa sen käsittelyyn relevanttina perusteluna. Ohittaminen osoittaa, että Katja pitää Olgan vastausta riittämättömänä tai tilanteeseen sopimattomana. Tämä näkyy myös jatkosta:

9. Clayman ja Heritage (2002) esittävät, että uutishaastatteluissa esimerkin 4a alun (r. 1-3) pohjustusta vastaavien jaksojen funktio voi olla esimerkiksi kysymyksen kontekstualisoiminen (mts. 192-193) ja kysymyksen tai sen taustaoletusten problematisoiminen (tightening question agenda, mts. 201-203). Esimerkissämme kyse voi olla molemmista: jo aiemmin esitettyä kysymystä kontekstualisoidaan uudelleen vertaamalla sitä suomenkieliseen tiedotteeseen ja samalla tarkennetaan kysymyksen alaa sulkemalla keskustelusta pois suomenkielinen tiedotustarve. 
(4b) Tarvitaanko Ylelle

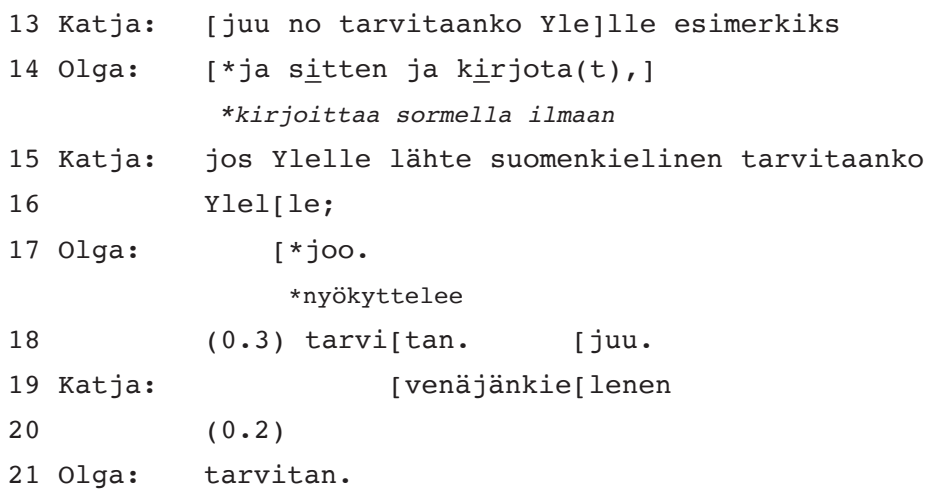

Katja ottaa nyt fokukseen yhden tiedotteen mahdollisista vastaanottajista, Yleisradion, ja kysyy, tarvitseeko sinne lähettää venäjänkielistä tiedotetta (r. 13). Heti tämän jälkeen hän rinnastaa jälleen venäjänkielisen tiedotteen suomenkieliseen tiedotteeseen (r. 15) ja kysyy sen jälkeen saman kysymyksen vielä uudelleen (r. 15-16). Katjan kysymys on muodoltaan vaihtoehtokysymys, joka siis projisoi joko myöntävää tai kieltävää vastausta. Kuten edellisessä esimerkissä 4 a, venäjänkielisen tiedotteen kontrastoiminen tarpeelliseen suomenkieliseen tiedotteeseen ja ylipäänsä tarpeellisuuden kyseenalaistaminen pitkän aiheesta käydyn keskustelun jälkeen luovat odotuksen pikemminkin kieltävästä vastauksesta (ks. myös Clayman \& Heritage 2002: 207). Samalla korostuu tarve esittää perusteluja mahdolliselle myöntävälle vastaukselle. Katjan kysymys muistuttaa tässä mielessä esimerkissä 1 esiteltyä Riston kysymystä Georgin työkokemuksesta. Kyse on siis kysymystyypistä, jollaisia Steensig ja Heinemann (2013) nimittävät kyllä/ei+-kysymyksiksi. Riittävä vastaus tällaiseen kysymykseen tarjoaa kiellon tai myönnön lisäksi myös jonkinlaista lisätietoa.

Olga vastaa kysymykseen kuitenkin kategorisen myöntävästi - ilman perusteluja esittäen yhteensä neljä myöntävää vastausta. Hän aloittaa vastauksensa joo-partikkelilla jo Katjan vuoron loppua ennakoiden (r. 17) ja tukee vastaustaan kehollisesti nyökyttelemällä. Pienen tauon jälkeen hän vielä toistaa kysymyksen verbin tarvitan (r. 18). Tämän kanssa päällekkäispuhunnassa Katja täydentää vielä kysymystään (r. 15-16) sanalla venäjänkielenen (r. 19), joka täsmentää vastakkainasettelua suomenkielisen tiedotteen kanssa. Tähänkin Olga reagoi hieman Katjan vuoron loppua ennakoiden myöntävällä partikkelilla (juu r. 18) ja toistamalla jälleen verbin lyhyen tauon jälkeen (r. 21). Sekä responssipartikkeli joo (/juu) että verbin toistaminen ovat rakenteellisesti mukautuneita eli muodollisesti samanlinjaisia vastauksia vaihtoehtokysymykseen (type-conforming answers, Raymond 2003; ks. myös Sorjonen 2001b). ${ }^{10}$ Olga ottaa siis

10. Kuten jo edellä mainitsimme, verbin toistaminen on oletusarvoinen vastaus silloin, kun kysymys on esitetty puhtaasti tiedonhakutarkoituksessa, ja joo silloin, kun kysyjä hakee pikemminkin vahvistusta tiedolle (Sorjonen 2001b: 424). Tässä tilanteessa vastausvaihtoehtojen ero ei tunnu merkittävältä, sillä Katjan episteeminen asema kysyjänä on (ainakin Olgalle) epäselvä. 
vahvasti kantaa venäjänkielisen tiedotteen tarpeellisuuden puolesta mutta ei täydennä vastaustaan perusteluilla.

Esimerkistä $4 c$ näemme, että Katja ei edelleenkään tyydy tähän vastaukseen. Tilanne kuitenkin etenee, sillä katkelman aikana Olga esittää pidemmän perustelevan vuoron (r. 29 alkaen):

(4c) Spektr ei julkaise

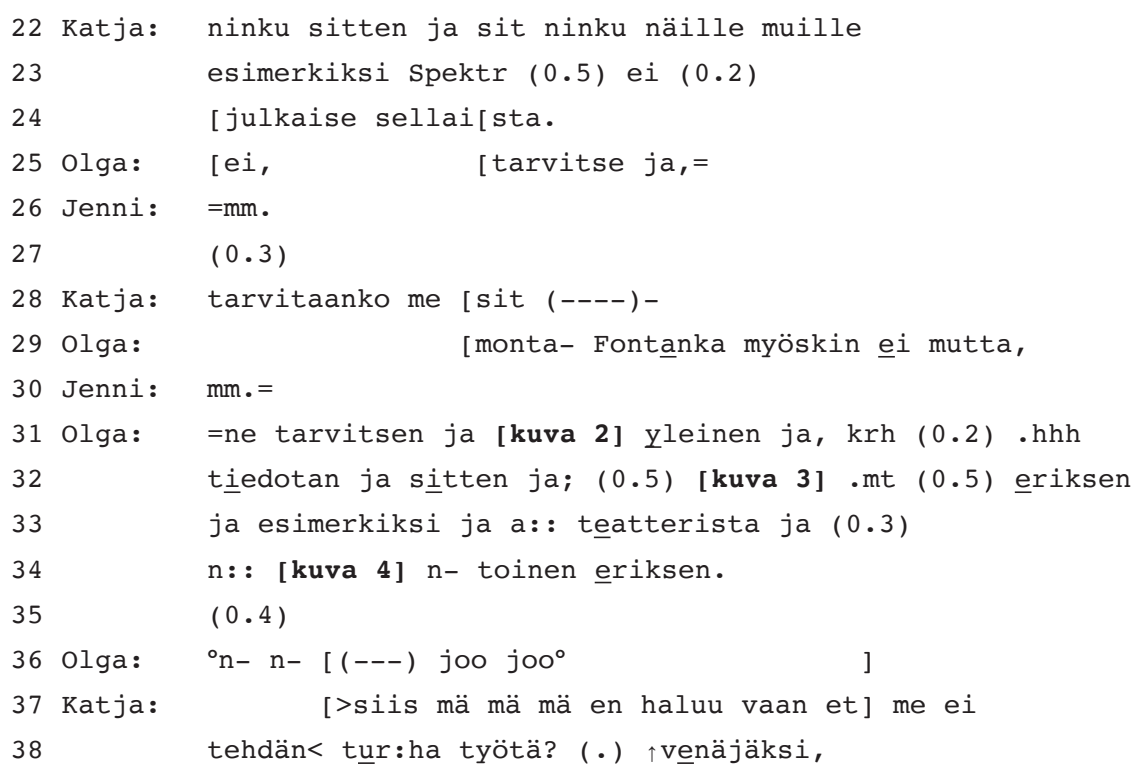

Katkelman alussa Katja muuttaa hieman strategiaa: hän ei enää esitä kysymystä, tarvitseeko Spektriin lähettää tiedotetta, vaan esittää väitteen, jonka mukaan lehti ei julkaise tällaisia tiedotteita (r. 23-24). Väitteeseen sisältyvä oletus siis on, että tiedotetta ei kannata lähettää, koska sitä ei kuitenkaan julkaistaisi. Olga vahvistaa Katjan väitteen (r. 25). Tätä seuraa lyhyt tauko (r. 27), jonka aikana Olga ei esitä vasta-argumentteja tai lisäselityksiä väitteelle, vaikka se on jossain määrin ristiriidassa hänen aiemman kantansa kanssa.

Katja lähtee jälleen kerran toistamaan kysymystä tiedotteen tarpeellisuudesta (r. 28). Tässä vaiheessa Olga kuitenkin keskeyttää Katjan ja aloittaa kantansa perustelun. Ensin hän ottaa esiin vielä tiedotteen kolmannen mahdollisen vastaanottajan, joka ei julkaisisi tällaisia tiedotteita (r. 29). Nyt Olga kuitenkin jatkaa vuoroaan mutta-partikkelilla (r. 29), joka ilmaisee, että hän on aloittamassa vasta-argumenttia. Partikkelia seuraa pitkähkö vuoro (r. 31-34), jolla Olga perustelee tiedotteen tarvetta. Perustelua seuraavasta Katjan vuorosta (r. 37-38) näkyy kuitenkin, ettei tämäkään Olgan vuoro vastaa aivan odotuksia: Katja nimittäin jatkaa perustelemalla venäjänkielisen tiedotteen tarpeellisuuden kyseenalaistamista turhan työn välttämisellä.

Miksi Olgan perustelut sitten eivät vieläkään riitä ongelmatilanteen selvittämiseen? Syitä voi hakea sekä vuoron muotoilusta että sisällöstä. Ensinnäkään vuoro ei ole erityisen sujuva: se sisältää taukoja, pitkitettyjä äänteitä, kurkun selvittämistä, hengitystä 
sekä ja-konjunktion toistuvaa käyttöä. Tuottamisen vaikeudesta kertoo myös se, että Olga elehtii käsillään koko vuoron ajan, myös taukojen aikana (ks. kuvat 2-4); eleiden käytön on todettu lisääntyvän kognitiivisen ponnistelun ja puhumisen vaikeutumisen yhteydessä (Goldin-Meadow 2003) sekä silloin, kun puhutaan muuta kuin itselle vahvinta kieltä (Gullberg 1998). Syntaksin näkökulmasta vuoro on hyvin fragmentaarinen, mikä osaltaan vaikeuttaa sen tulkitsemista. Vuorosta kuitenkin välittyy kokonaismerkitys, jonka mukaan toisaalta on tarve yleiselle tapahtumasta kertovalle tiedotteelle ja toisaalta erillisille osatapahtumia (esimerkiksi teatteriesitystä) koskeville tiedotteille. Tässäkin tapauksessa vuoro ennemminkin kertoo, millaisia tiedotteita Olgan mielestä tarvitaan, kuin perustelee sitä, miksi niitä tarvitaan.

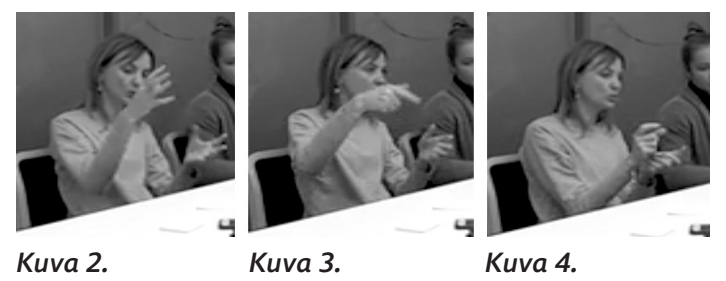

Esimerkit 4a-c osoittavat, että vaikka responsiiviset vuorot sinänsä olisivat vastauksia esitettyihin kysymyksiin, tämä ei aina riitä. Olemme pyrkineet näyttämään, että esimerkeissä Olga tulkitsee vaihtoehtokysymyksen liian kapeasti eikä osoita ymmärtävänsä, että pelkän kiellon tai myönnön lisäksi tilanteessa tarvittaisiin myös tarkempia perusteluja. Tämä näkyy kysymyssekvenssin pitkittymisenä: suunnilleen samansisältöiseen kysymykseen palataan useita kertoja, mitä voi pitää selvänä merkkinä annettujen vastausten riittämättömyydestä (ks. esim. Clayman \& Heritage 2002: 198). Pitkittynyt kysymyssekvenssi katkeaa lopulta vasta, kun säätiön johtaja muotoilee asian uudelleen (ei litteraatissa).

Esimerkki 4 on kiinnostava myös kakkoskielisyyden merkityksen tulkitsemisen kannalta. Ensinnäkin tilanne muistuttaa edellisen luvun esimerkkiä 3 siten, että siinä ei näy eksplikoitua orientoitumista kakkoskielisyyteen. Mahdollinen ulospääsy pitkittyneestä tilanteesta voisi olla (lyhytkin) vaihto venäjään, sillä sekä Katja että Olga ovat ensikieleltään venäjänkielisiä. Näin ei kuitenkaan tehdä, mikä voi kertoa siitä, että puhujat eivät näe ongelmaa kielitaitokysymyksenä, tai siitä, ettei kyseisessä kokouksessa haluta käyttää kieltä, jota kaikki kokouksen osallistujat eivät osaa. Silti voidaan pohtia, missä määrin esimerkiksi Katjan kysymysten taka-ajatuksen hahmottamisen vaikeudessa on kyse kielellisistä ymmärtämisen ongelmista. Yhtä lailla Olgan toiminta esimerkissä $4 \mathrm{C}$ voi viitata tuottamisen ongelmiin, mikä osaltaan voisi selittää muissakin esimerkeissä perustelujen vähäisyyden; merkkejä mahdollisista tuottamisen ongelmista ovat myös esimerkiksi tauko ja suunnitteluäänteet (esim. 4a, r. 7, 9 ja samojen vastausten toisto (esim. 4b r. 17-18, 21). Perustelujen esittäminen on joka tapauksessa pelkkää myöntämistä vaativampi kielellinen toiminto. On kenties perusteltua pohtia, olisiko Olga pystynyt perustelemaan kantansa paremmin jollakin vahvemmalla kielellään tai jos hän olisi saanut enemmän aikaa perustelujen muotoiluun. Tätä emme kuitenkaan voi päätellä suoraan esimerkin perusteella. 


\section{Työelämän kakkoskielinen vuorovaikutus: ongelmia ja ratkaisuja}

Olemme tässä artikkelissa soveltaneet keskustelunanalyysin metodia monikielisen työelämän vuorovaikutuksen ongelmakohtien analysointiin. Tutkimuskohteeksi valikoituivat kakkoskielisten tuottamat responsiiviset vuorot, jotka ovat jollakin tavoin ongelmallisia suhteessa edeltävään vuorovaikutukseen. Kutsumme tällaisia vuoroja erilinjaisiksi. Edellä olemme esitelleet kolmenlaisia erilinjaisia responsiivisia vuoroja: 1) sellaisia, jotka eivät edusta edellisen vuoron projisoimaa toimintoa (esim. 1-2), 2) sellaisia, joiden edustama toiminto on jostakin syystä epäselvä (esim. 3), ja 3) sellaisia tapauksia, joissa vuoro ei tunnu vastaavan riittävän hyvin edellisten vuorojen projisoimiin odotuksiin (esim. 4a-c). Analysoidut esimerkit osoittavat, että erilinjaisuutta ratkotaan ongelmallista vuoroa seuraavassa vuorovaikutuksessa monella tavalla. Esimerkiksi niissä voi tapahtua vaihto puhujan vahvemmalle kielelle (esim. 1-2). Useimmissa esimerkeissä erilinjaista vuoroa seuraa tauko (esim. 1, 3, 4a, 4b) ja jonkinlaisia uudelleenmuotoiluja (esim. 1, 3, 4a-c). Lisäksi esimerkissä 3 tehdään eksplisiittinen tarkistuskysymys siitä, mitä ongelmallisella vuorolla on tarkoitettu. Ainoastaan esimerkin 2 tapausta ei käsitellä suoraan ongelmallisena, mitä olemme pohtineet tarkemmin esimerkin yhteydessä.

Mitä esimerkkimme sitten kertovat monikielisestä työelämän vuorovaikutuksesta ja kakkoskielisten vuorovaikutuksen ongelmista? Ensinnäkin erilinjaiset vuorot näyttävät olevan suhteessa kielitaitoon. Vaikka ongelmallisia erilinjaisia vuoroja tuottavat epäilemättä silloin tällöin kaikki puhujat, ainakin tästä aineistosta esiin on noussut ainoastaan kakkoskielisten esittämiä ongelmallisia erilinjaisuuksia. Esimerkkien suhdetta kakkoskielisyyteen voi tarkastella myös siitä näkökulmasta, kertovatko ongelmakohdat ymmärtämisen vai tuottamisen ongelmista - vai molemmista. Esimerkeissä ei nouse esiin tapauksia, joissa kakkoskielinen osallistuja ei ymmärtäisi jotain kielellistä ilmausta, mutta sen sijaan ymmärtämisen ongelmia tuntuu ilmenevän toiminnan tasolla. Kakkoskieliset osallistujat eivät aina tunnista edeltävän vuoron edustamaa toimintoa tai sen taustaoletuksia eivätkä siksi pysty vastaamaan kaikkiin tilanteen heille asettamiin odotuksiin - mikä voikin aineiston edustamissa vapaamuotoisissa kokouksissa olla hyvin vaativa tehtävä. Ongelmaan reagoidaan esimerkeissä 1 ja 3 siten, että etujäsenen esittänyt puhuja ja muut osallistujat pyrkivät korjaamaan väärinymmärryksen käännöksen, korjausaloitteen ja itsekorjauksen avulla. Esimerkissä 2 muut osallistujat eivät puutu ongelmaan, mutta toimintasekvenssi jää selvästi kesken eikä topiikkia vaihtava kakkoskielinen puhuja itse orientoidu toimintansa keskeyttävään luonteeseen. Ongelmia on ymmärtämisen lisäksi myös tuottamisessa: kakkoskielisten puhujien vuorojen kielellinen epätarkkuus voi tehdä niiden tulkinnasta vaikeaa (esim. 3, 4c), jolloin muut eivät pysty tunnistamaan niiden edustamia toimintoja; lisäksi haastavien kielellisten toimintojen suorittaminen ei aina onnistu (esimerkin 4c perustelut). Raja ymmärtämisen ja tuottamisen ongelmien välillä ei kuitenkaan ole selvä. Toisinaan voi myös olla vaikea sanoa, onko ongelmatilanteissa kyse kakkoskielisen puhujan puutteellisista kielellisistä resursseista (joko ymmärtämisessä tai tuottamisessa) vai ammatilliseen tai tietyn työpaikan kielenkäyttöön sosiaalistumisesta (Roberts 2010) ylipäänsä. Jälkimmäinen on tietenkin haaste yhtä lailla ensikieltään puhuville kuin kakkoskielisille. 
Vuorovaikutuksen ajoittaisista ongelmista huolimatta esimerkeistämme voi nostaa esiin myös keinoja, joilla monikielistä kokousvuorovaikutusta voi sujuvoittaa. Kokousten osallistujilla on monenlaisia tapoja ratkoa kielellisesti ongelmallisia tilanteita. $\mathrm{He}$ käyttävät esimerkiksi joustavasti eri kieliä: jos ymmärtäminen tai tuottaminen suomeksi tuottaa vaikeuksia, asian voi hetkellisesti hoitaa jollain muulla osallistujille yhteisellä kielellä. Uudelleenmuotoilut ja korjausaloitteet taas antavat kokousten kakkoskieliselle osallistujalle useita tilaisuuksia tarkistaa ymmärtämistään tai täsmentää omaa vuoroaan. Kokousten osallistujat suhtautuvat myös varsin hienotunteisesti kielellisten resurssien rajallisuuteen, mikä tukee ammatillisten roolien ensisijaisuutta työtilanteissa. Jos taas kuvaamiamme ongelmallisia erilinjaisuuksia haluttaisiin vähentää, toisinaan sekä tilannekohtaiset tavoitteet että ymmärtämisen ongelmat kannattaisi tehdä eksplisiittisemmin näkyviksi.

Kakkoskielisyyteen liittyvillä ongelmilla on edellä kuvattua laajempiakin vaikutuksia työelämässä. Ensinnäkin puutteelliset kielelliset resurssit voivat vaikuttaa siihen, miten muut arvioivat työntekijän ammatillista osaamista. Miten voi vaikuttaa pätevältä, jos ei osaa tulkita tilanteita tai pysty ilmaisemaan ajatuksiaan täysipainoisesti? Ammatillinen osaaminen voi toisaalta myös jäädä piiloon, jos kynnys ottaa puheenvuoro kokouksessa on liian korkea. Kyse on eräänlaisesta noidankehästä: kielitaito saattaa vaikuttaa kielteisesti siihen, miten muut arvioivat työntekijän ammatillista kompetenssia (Firth 2009; esimiehen näkökulmasta Kalliokoski 2017), mutta kielitaitoa ei pääse kehittämään, jos ei ala käyttää kieltä työtilanteissa.

Yhtenä ratkaisuna näemme työyhteisöjen kielitietoisuuden kasvattamisen. Kielellisistä ja vuorovaikutuksellisista kysymyksistä (esimerkiksi kielivalinnoista ja kakkoskielisten toiveista harjoitella kieltä) kannattaa keskustella työyhteisöissä. Ensinnäkin se auttaa muita kuin kakkoskielisiä ymmärtämään kakkoskielisen erityisongelmia: vaativienkin vuorovaikutustilanteiden kielellisistä ongelmista voidaan selvitä, mikäli osallistujilla on kyky tunnistaa kielitaidosta johtuvat ongelmat sekä keinoja käsitellä ongelmatilanteita. Toisaalta kielitietoinen työyhteisö voi tukea kakkoskielisten työntekijöiden kielitaidon kehittymistä esimerkiksi tarjoamalla heille tilaisuuksia sekä käyttää kieltä merkityksellisissä tilanteissa että saada siitä palautetta. Kakkoskielisten työntekijöiden kielitaidon kehittyminen taas edistäisi vuorovaikutuksen sujuvuutta ja parantaisi heidän mahdollisuuksiaan hyödyntää ammatillista osaamistaan.

\section{Lähteet}

Aldashev, Alisher - Gernandt, Johannes - Thomsen, Stephan L. 2009: Language usage, participation, employment and earnings. Evidence for foreigners in West Germany with multiple sources of selection. - Labour Economics 16 s. 330-341. https://doi. org/10.1016/j.labeco.2008.11.004.

Asmuss, Birte - Oshima, SAe 2012: Negotiation of entitlement in proposal sequences. - Discourse Studies 14 s. 67-86. https://doi.org/10.1177/1461445611427215.

Boden, Deirdre 1994: The business of talk. Organizations in action. Cambridge: Polity Press. Bolden, Galina B. 2016: A simple da? Affirming responses to polar questions in Russian con- 
versation. - Journal of Pragmatics 10o s. 40-58. https://doi.org/10.1016/j.pragma.2015.07.010.

Budría, Santiago - Colino, Alberto - Martínez de Ibarreta, Carlos 2018:

The impact of host language proficiency on employment outcomes among immigrants in Spain. - Empirica. https://doi.org/10.1007/s10663-018-9414-x.

Clayman, Steven - Heritage, John 2002: The news interview. Journalists and public figures on the air. Cambridge: Cambridge University Press.

Couper-Kuhlen, Elizabeth - Ono, Tsuyoshi 2007: 'Incrementing' in conversation. A comparison of practices in English, German and Japanese. - Pragmatics 17 s. 513-552. https://doi.org/10.1075/prag.17.4.02cou.

DJORDJILOVIC, OLGA 2012: Displaying and developing team identity in workplace meetings. A multimodal perspective. - Discourse Studies 14 s. 111-127. https://doi. org/10.1177/1461445611427205.

Dustmann, Christian - Fabbri, Francesca 2003: Language proficiency and labour market performance of immigrants in the UK. - The Economic Journal 113 s. 695-717. https://doi.org/10.1111/1468-0297.to1-1-00151.

Eskildsen, Sören W. - Theodórsdóttir, GuĐrún 2017: Constructing L2 learning spaces. Ways to achieve learning inside and outside the classroom. - Applied linguistics 38 s. 143-164. https://doi.org/10.1093/applin/amvo10.

Firth, Alan 2009: Doing not being a foreign language learner. English as a lingua franca in the workplace and (some) implications for SLA. - International Review of Applied Linguistics in Language Teaching 47 s. 127-156. https://doi.org/10.1515/iral.2009.006.

GARDNER, ROD 2001: When listeners talk. Response tokens and listener stance. Amsterdam: John Benjamins.

Goldin-Meadow, Susan 2003: Hearing gesture. How our hands help us think. Cambridge: Belknap Press of Harvard University Press.

Gullberg, Marianne 1998: Gesture as a communication strategy in second language discourse. A study of learners of French and Swedish. Lund: Lund University Press.

Hakulinen, Auli 2016: Lauserakenteet. - Melisa Stevanovic \& Camilla Lindholm (toim.), Keskustelunanalyysi. Kuinka tutkia sosiaalista toimintaa ja vuorovaikutusta s. 122-142. Tampere: Vastapaino.

Hazel, Spencer - Svennevig, Jan 2018: Multilingual workplaces. Interactional dynamics of the contemporary international workforce. - Journal of Pragmatics 126 s. 1-9. https:// doi.org/10.1016/j.pragma.2017.11.005.

Heritage, John 1996 [1984]: Harold Garfinkel ja etnometodologia. Suom. Ilkka Arminen, Outi Paloposki, Anssi Peräkylä, Sanna Vehviläinen \& Soile Veijola. Helsinki: Gaudeamus.

- 2012: The epistemic engine. Sequence organization and territories of knowledge. - Research on Language and Social Interaction 45 s. 30-52. https://doi.org/10.1080/o8351813.2012.646685.

Heritage, John - Raymond, Geoffrey 2005: The terms of agreement. Indexing epistemic authority and subordination in talk-in-interaction. - Social Psychology Quarterly 68 s. 15-38. https://doi.org/10.1177/019027250506800103.

Honkanen, Suvi 2012: Kielioppi ja tekstilaji. Direktiivin muotoilusta viraston ryhmäkirjeissä. Helsinki: Helsingin yliopisto. http://urn.fi/URN:ISBN:978-952-10-7731-9.

JÄPPINEN, TuUla 2010: Suomi (S2) korkeakoulutettujen työssä. Millainen kielitaito riittää? - Mikael Garant \& Mirja Kinnunen (toim.), AFinLA-e Soveltavan kielitieteen tutkimuksia 2 s. 4-16.

- 2011: Suomen kielen taidon riittävyys yritysten aikapaineisissa puhetilanteissa esimiesten ja työharjoittelijoiden kuvaamana. - Puhe ja kieli 31 s. 193-214.

KALLIOKOSKI, JYRKI 2017: "Good administrative language" from the perspective of public ad- 
ministrators with L2 backgrounds. - Journal of Estonian and Finno-Ugric Linguistics 8 (1) s. 61-77. https://doi.org/10.12697/jeful.2017.8.1.04.

Kirilova, Marta Kunov 2013: All dressed up and nowhere to go. Linguistic, cultural and ideological aspects of job interviews with second language speakers of Danish. København: Københavns Universitet, Det Humanistiske Fakultet.

KoмPPA, JoHANNA 2015: Työnantajan odotukset, työntekijän vastuu ja työyhteisön tuki. Näkökulmia korkeakoulutettujen maahanmuuttajien ammatillisen suomen oppimiseen.

- Jyrki Kalliokoski, Karita Mård-Miettinen \& Tarja Nikula (toim.), Kieli koulutuksen resurssina. Vieraalla ja toisella kielellä oppimisen ja opetuksen näkökulmia s. 168-185. AFinLA-e 8.

Komppa, Johanna - Jäppinen, Tuula - Herva, Marja - Hämäläınen, Taija 2014: Korkeakoulutuksen ammatilliset suomi toisena kielenä -viitekehykset. Aatos-artikkelit. Metropolia AMK. http://www. metropolia.fi /palvelut/julkaisutoiminta/julkaisusarjat/ aatos-artikkelit/komppa-jappinen- herva-hamalainen/ (18.6.2018).

Kotilainen, Lari - Lehtimaja, Inkeri (tulossa) 2019: Kielenvaihto monikielisissä kokouksissa. Tilanteisuus, osallistujien kielitaito ja vuorovaikutuksen sujuvuus. - Puhe ja kieli 39.

Kurhila, SAlla 2005: Different orientations to grammatical correctness. - Keith Richards \& Paul Seedhouse (toim.), Applying conversation analysis s. 143-158. Basingstoke: Palgrave Macmillan.

2006: Second language interaction. Amsterdam: John Benjamins.

Kurhila, Salla - Lehtimaja, Inkeri 2018: Dealing with numbers. Nurses informing doctors and patients about test results. - Discourse Studies 21 s. 180-198.

_- (tulossa) 2019: Ammattikielen tilanteisuus kielenoppimisen haasteena. Esimerkkinä hoitoala. - Lari Kotilainen, Salla Kurhila \& Jyrki Kalliokoski (toim.), Kielenoppiminen luokan ulkopuolella. Helsinki: Suomalaisen Kirjallisuuden Seura.

Kurhila, Salla - Lindholm, Camilla 2016: Ymmärtämisen haasteet. - Melisa Stevanovic \& Camilla Lindholm (toim.), Keskustelunanalyysi. Kuinka tutkia sosiaalista toimintaa ja vuorovaikutusta s. 259-275. Tampere: Vastapaino.

Larja, Liisa - Sutela, Hanna 2015: Työllisyys. - Tarja Nieminen, Hanna Sutela \& Ulla Hannula (toim.), Ulkomaista syntyperää olevien työ ja hyvinvointi Suomessa 2014 s. 71-82. Helsinki: Tilastokeskus.

Lehtimaja, Inkeri (tulossa 2019): Ammatillisen kielitaidon oppiminen vuorovaikutuksessa. Kakkoskieliset sairaanhoitajaharjoittelijat ohjaustilanteissa. - Lari Kotilainen, Salla Kurhila ja Jyrki Kalliokoski (toim.), Kielenoppiminen luokan ulkopuolella. Helsinki: Suomalaisen Kirjallisuuden Seura.

Lehtonen, Heini 2015: Tyylitellen. Nuorten kielelliset resurssit ja kielen sosiaalinen indeksisyys monietnisessä Helsingissä. Helsinki: Helsingin yliopisto. http://urn.fi/ URN:ISBN:978-951-51-1333-7.

Lüdi, Georges - Höchle, Katharina - Yanaprasart, Patchareerat 2010: Plurilingual practices at multilingual workplaces. - Bernd Meyer \& Birgit Apfelbaum (toim.), Multilingualism at work. From policies to practices in public, medical and business settings s. 211-234. Amsterdam: Benjamins.

Lønsmann, DORTE 2014: Linguistic diversity in the international workplace. Language ideologies and processes of exclusion. - Multilingua 33 s. 89-116. https://doi.org/10.1515/ multi-2014-0005.

Maynard, Douglas W. 1980: Placement of topic changes in conversation. - Semiotica 30 s. 263-29o. https://doi.org/10.1515/semi.1980.30.3-4.263.

Menz, Florian 2017: Business meetings. - Gerlinde Mautner \& Franz Rainer (toim.), Hand- 
book of business communication. Linguistic Approaches s. 111-130. Berlin: Walter de Gruyter. Mıккоla, PiıA 2014a: Arvioivasta lomaketekstistä hienovaraisiin sananvalintoihin. Vuoron muotoilu ja rekontekstualisaatio kehityskeskustelun topikaalisissa siirtymissä. - Virittäjä 118 s. 525-553.

_ 2014b: Samanlinjaisuus ja erilinjaisuus kehityskeskustelussa. Alaisen mahdollisuudet vaikuttaa topiikkien määrittelyyn ja tulkintaan. - Puhe ja kieli 34 s. 175-199.

Negretti, Raffaella - Garcia-Yeste, Miguel 2015: "Lunch keeps people apart". The role of English for social interaction in a multilingual academic workplace. - Multilingua 34 s. 93-118. https://doi.org/10.1515/multi-2014-1038.

Niemi, JARкко 2015: Myönnyttelyn käytänteitä. Erimielisyys ja yhteisymmärryksen rakentaminen vuorovaikutuksessa. Helsinki: Helsingin yliopisto. http://urn.fi/ URN:ISBN:978-951-51-0603-2.

Nieminen, TARja 2015: Työttömyys ja työvoiman ulkopuolella olevat. - Tarja Nieminen, Hanna Sutela \& Ulla Hannula (toim.), Ulkomaista syntyperää olevien työ ja hyvinvointi Suomessa 2014 s. 121-133. Helsinki: Tilastokeskus.

Nissi, RiIkKa - Lehtinen, Esa 2016: Negotiation of expertise and multifunctionality. PowerPoint presentations as interactional activity types in workplace meetings. - Language \& Communication 48 s. 1-17. https://doi.org/10.1016/j.langcom.2016.01.003.

PAANANEN, JENNY 2016: Kuinka lääkärit korjaavat kysymyksiään? Kysymysten uudelleenmuotoilu monikulttuurisilla lääkärin vastaanotoilla. - Virittäjä 120 s. 552-579.

2019: Yhteisymmärryksen rakentaminen monikulttuurisilla lääkärin vastaanotoilla. Annales Universitatis Turkuensis C 465. Turku: Turun yliopisto. http://urn.fi/ URN:ISBN:978-951-29-7557-0.

Pomerantz, Anita 1984: Agreeing and disagreeing with assessments. Some features of preferred/dispreferred turn shapes. - J. Maxwell Atkinson \& John Heritage (toim.), Structures of social action s. 57-101. Cambridge: Cambridge University Press.

Pomerantz, Anita - Heritage, John 2013: Preference. - Jack Sidnell \& Tanya Stivers (toim.), Handbook of conversation analysis s. 210-228. Oxford: Wiley-Blackwell.

Puhe ja kieli 4/2011. Suomi toisena kielenä työelämässä -teemanumero.

Pälli, Pekka - Lehtinen, Esa 2015: Practical genre knowledge as professional competence. The case of managerial meetings. - Lubie Grujicic-Alatriste (toim.), Linking discourse studies to professional practice s. 109-127. Bristol: Multilingual Matters.

RaevaAra, Liisa - Ruusuvuori, Johanna - HaAkana, Markku 2001: Institutionaalinen vuorovaikutus ja sen tutkiminen. - Johanna Ruusuvuori, Markku Haakana \& Liisa Raevaara (toim.), Institutionaalinen vuorovaikutus. Keskustelunanalyyttisia tutkimuksia s. 11-38 Helsinki: Suomalaisen Kirjallisuuden Seura.

RAYMOND, GeOFFREY 2003: Grammar and social organization. Yes/no interrogatives and the structure of responding. - American Sociological Review 68 s. 939-967. https://www.jstor. org/stable/1519752.

Roberts, Celia 2010: Language socialization in the workplace. - Annual Review of Applied Linguistics 30 s. 211-227. https://doi.org/10.1017/So267190510000127.

Routarinne, SARA - Ogden, Richard 2005: The communicative functions of final rises in Finnish intonation. - Phonetica 62 s. 160-175. https://doi.org/10.1159/oooogoog6.

Schegloff, Emanuel A. 1968: Sequencing in conversational openings. - American Anthropologist 70 s. 1075-1095. https://doi.org/10.1525/aa.1968.70.6.02a00030.

Schegloff, Emanuel A. - Sacks, Harvey 1973: Opening up closings. - Semiotica 8 s. 289-327. https://doi.org/10.1515/semi.1973.8.4.289. 
SORJOnen, MARJA-LEEna 2001a: Responding in conversation. A study of response particles in Finnish. Amsterdam: John Benjamins.

2001b: Simple answers to polar questions. The case of Finnish. - Margret Selting \& Elizabeth Couper-Kuhlen (toim.), Studies in interactional linguistics. Amsterdam: John Benjamins.

SteENSIG, JАКОв 2013: Conversation analysis and affiliation and alignment. - Carol A. Chapelle (toim.), The encyclopedia of applied linguistics. Oxford: Blackwell Publishing. https:// doi.org/10.1002/9781405198431.wbealo196.

Steensig, Jаков - Heinemann, Trine 2013: When 'yes' is not enough - as an answer to a yes/no question. - Beatrice Szczepek Reed \& Geoffrey Raymond (toim.), Units of talkUnits of action. Studies in language and social interaction 25. Amsterdam: Benjamins.

Stevanovic, Melis a 2013: Deontic rights in interaction. A conversation analytic study on authority and cooperation. Helsinki: University of Helsinki, Department of Social Sciences. http://urn.fi/URN:ISBN:978-952-10-7685-5.

Stevanovic, Melisa - Lindholm, Camilla (toim.) 2016: Keskustelunanalyysi. Kuinka tutkia sosiaalista toimintaa ja vuorovaikutusta. Tampere: Vastapaino.

Stevanovic, Melisa - Peräkylä, Anssi 2012: Deontic authority in interaction. The right to announce, propose and decide. - Research on Language and Social Interaction 45 s. 297-321. https://doi.org/10.1080/08351813.2012.699260.

Stivers, TANyA 2008: Stance, alignment, and affiliation during storytelling: when nodding is a token of affiliation. - Research on Language and Social Interaction $41 \mathrm{~s} .31-57$. https://doi. org/10.1080/08351810701691123.

Stivers, Tanya - Hayashi, Makoto 2010: Transformative answers. One way to resist a question's constraints. - Language in Society 39 s. 1-25. https://doi.org/10.1017/ Soo47404509990637.

Stivers, Tanya - Mondada, Lorenza - Steensig, Jakов 2011: Knowledge, morality and affiliation in social interaction. - Tanya Stivers, Lorenza Mondada \& Jakob Steensig (toim.), The morality of knowledge in conversation s. 3-26. Cambridge: Cambridge University Press.

STIVERS, TANYA - RoBinson, JEFFREY D. 2006: A preference for progressivity in interaction. - Language in Society 35 s. 367-392. https://doi.org/10.1017/So047404506060179.

Strömmer, Maiju 2017: Mahdollisuuksien rajoissa. Neksusanalyysi suomen kielen oppimisesta siivoustyössä. Jyväskylä: Jyväskylän yliopisto. http://urn.fi/URN:ISBN:978-951-39-7265-3.

SvenNEVIG, JAN 2012: Interaction in workplace meetings. - Discourse Studies 14 s. 3-10. https://doi.org/10.1177/1461445611427203.

Thompson, Sandra A. - Fox, Barbara A. - Couper-Kuhlen, Elizabeth 2015: Grammar in everyday talk. Building responsive actions. Cambridge: Cambridge University Press.

Tillilä, Ulla - Karvinen, Kati (toim.) 2017: Elämän ja kuoleman tekstit. Kirjoittaminen sosiaali- ja hoitotyössä. Helsinki: Kotimaisten kielten keskus.

VArjonen, Sirkku - Zamiatin, Aleksandr - Rinas, Marina 2017: Suomen venäjänkieliset tässä ja nyt. Tilastot, tutkimukset, järjestökentän kartoitus. Helsinki: Cultura-säätiö.

Virtanen, Aija 2017: Toimijuutta toisella kielellä. Kansainvälisten sairaanhoitajaopiskelijoiden ammatillinen suomen kielen taito ja sen kehittyminen työharjoitteluissa. Jyväskylä: Jyväskylän yliopisto. http://urn.fi/URN:ISBN:978-951-39-7021-5.

VisK = Hakulinen, Auli - Vilkuna, Maria - Korhonen, Rittta - Koivisto, Vesa - Heinonen, Tarja Rittta - Alho, Irja 2004: Iso suomen kielioppi. Helsinki: Suomalaisen Kirjallisuuden Seura. Verkkoversio. http:/scripta.kotus.fi/visk URN:ISBN:978-952-5446-35-7 (1.10.2019). 


\section{Disaligned turns of second-language speakers in workplace meeting interaction}

An increasing number of workplaces face challenges related to the limited language skills of their employees. This article takes a conversation analytical view of the problems that educated second-language (L2) speakers encounter in workplace meeting interactions. The data employed consists of 20 hours of video recordings taken at a Finnish cultural organisation.

The article concentrates on problems in the progressivity of interaction related to responsive turns produced by L2 speakers of Finnish. The problematic turns are seen as disaligned, as they do not meet the expectations projected by previous turns. Three kinds of turn are discussed: 1) turns that show that the speaker has not identified the expectations set by preceding turns, 2) turns that are unclear with regard to the activity they represent, and 3) turns that meet the expectations of previous turns inadequately.

The analysis shows that disaligned turns are followed by several problems with regard to the progressivity of interaction: e.g. pauses, reformulations, or repair initiations. Occasionally, other participants interpret the problems as displays of a lack of language skills, and they react by switching language. The article illustrates practices used to deal tactfully yet effectively with problems in the progress of interaction. The article asserts that, despite these problems, the opportunity to use and practice a second language is valuable both to L2 speakers and their work community. 


\section{Suomea toisena kielenä puhuvan työntekijän erilinjaiset vuorot kokousvuorovaikutuksessa}

Työelämän monikielistyessä yhä useammalla työpaikalla kohdataan haasteita, jotka liittyvät työntekijöiden rajalliseen kielitaitoon. Erityisesti korkeakoulutusta vaativat tehtävät edellyttävät abstraktien ja monitahoisten ilmiöiden kielentämistä, minkä lisäksi tilanteissa on pystyttävä ottamaan huomioon osallistujien institutionaaliset roolit ja niihin liittyvät odotukset. Tämä artikkeli tarkastelee keskustelunanalyysin keinoin, millaisia ongelmia kakkoskielisten työntekijöiden osallistumiseen liittyy kokousvuorovaikutuksessa. Aineistona käytetään erään kulttuurialan säätiön kokouksia (yhteensä 20 tuntia videomateriaalia), ja niissä tarkastellaan vuorovaikutuksen etenemisen ongelmakohtia, jotka liittyvät suomea toisena kielenä käyttävien työntekijöiden responsiivisiin vuoroihin. Tutkittavia vuoroja voidaan pitää erilinjaisina, sillä ne eivät vastaa edeltävien vuorojen niille asettamiin odotuksiin. Erilinjaisia vuoroja on kolmenlaisia: vuoroja, jotka osoittavat, ettei puhuja ole tunnistanut itseensä kohdistuvia odotuksia, vuoroja, joiden edustama toiminto on epäselvä, sekä vuoroja, joiden edustama toiminto on odotuksiin nähden riittämätön.

Analyysi osoittaa, millaisia ongelmia erilinjaiset vuorot aiheuttavat keskustelun etenemiselle: niistä seuraa esimerkiksi taukoja, uudelleenmuotoiluja tai korjausaloitteita. Muut osallistujat tulkitsevat toisinaan ongelman johtuvan kielitaidosta ja esimerkiksi vaihtavat kieltä. Kakkoskielisten puhujien erilinjaisissa vuoroissa limittyvätkin ymmärtämisen ja tuottamisen ongelmat, ja tilanteita saattaa vaikeuttaa myös institutionaalisiin rooleihin liittyvien taustaoletusten tunnistaminen. Artikkelissa osoitetaan, miten kakkoskielisissä kokouksissa tasapainoillaan työrooleja kannattelevan hienotunteisuuden ja ongelmien selvittelyä edistävän eksplisiittisyyden välillä. Mahdollisuus käyttää kieltä antaa joka tapauksessa kakkoskieliselle työntekijälle mahdollisuuden kehittää kielitaitoaan, mistä on pitkällä tähtäimellä hyötyä koko työyhteisölle.

Kirjoittajien yhteystiedot (addresses):

etunimi.sukunimi@helsinki.fi

Inkeri Lehtimaja toimii tutkijana Helsingin yliopistossa ja suomen kielen yliopistonlehtorina Aalto-yliopistossa, Lari Kotilainen suomen kielen yliopistonlehtorina Helsingin yliopistossa. 